\title{
MARKET ORIENTATION PADA PT GUNUNG HIJAU MASARANG BERDASARKAN SKALA MARKOR
}

\author{
Alan R. Rombon \\ Leonardus R. Rengkung \\ Jen Tatuh
}

\begin{abstract}
This study aims to know the Market Orientation (market intelligence, market intelligence dissemination, responsiveness of market intelligence). This research was conducted for three months from May until July 2017. The data used are primary data which is quantified by using Likert scale. The data taken by using survey method and use questioner to be distributed to 6 respondents in company. Questionnaires are used to identify market intelligence, market intelligence spread, responsiveness to market intelligence. Based on the results of research conducted at PT Gunung Hijau Masarang, the company's market orientation value was 67.29 percent. The company's market intelligence carried out customer service activities to know the consumer's response to the product. In the Market Intelligence Spread, Company companies understood market integrations such as informally discussing competitor strategies, formal and informal discussions of needs. Whereas in the responsiveness of market intelligence the Company understood market orientation towards the response to market integrity. The company received complaints such as if there is a defective product, a change of packaging This is an opportunity for the company to correct the performance of the company as well as the service system like this makes it easier to encourage companies to more sharply looked at consumer needs.*inkd*.
\end{abstract}

Keywords: market orientation, markor scale, PT Gunung Hijau Masarang.

\begin{abstract}
ABSTRAK
Penelitian ini bertujuan untuk mengetahui Market Orientation (intelejensi pasar, penyebarluasan intelejensi pasar, responsivitas atas intelegensi pasar). Penelitian ini dilaksanakan selama tiga bulan sejak bulan Mei sampai bulan Juli 2017. Data yang digunakan adalah data primer yang dikuantifikasikan dengan mennggunakan skala Likert. Data yang diambil dengan menggunakan metode survey serta menggunakan kuesioner dibagikan kepada 6 responden dalam perusahaan. Kuesioner digunakan untuk mengetahui intelejensi pasar, penyebarluasan intelejensi pasar, responsivitas atas intelegensi pasar. Berdasarkan hasil penelitian yang dilaksanakan di PT Gunung Hijau Masarang, nilai orientasi pasar perusahaan yaitu 67,29 persen. Intelegensi pasar perusahaan melakukan kegiatan pelayanan kebutuhan konsumen untuk mengetahui respon konsumen terhadap produk. Dalam Penyebaran Intelegensi pasar, perusahaan Perusahaan memahami integensi pasar seperti membicarakan secara informal tentang strategi pesaing, diskusi tentang kebutuhan secara formal maupun secara informal. Sedangkan dalam responsivitas intelegensi pasar Perusahaan memahami market orientation terhadap respon atas integensi pasar. Perusahaan menerima keluhan seperti jika ada produk yang rusak, perubahan kemasan Hal ini adalah kesempatan bagi perusahaan untuk mengkoreksi kinerja perusahaan serta sistem layanan seperti ini mempermudah mendorong perusahaan untuk lebih jeli melihat kebutuhan konsumen.*jnkd*.
\end{abstract}

Kata kunci: market orientation, skala markor, PT Gunung Hijau Masarang.

\section{PENDAHULUAN}

\section{Latar Belakang}

Perkembangan dunia bisnis khususnya di Indonesia yang sedang membangun ekonomi bangsanya sementara berkembang. Perkembangan teknologi juga yang semakin pesat yang memfasilitasi orang untuk berbisnis. Bisnis telah berkembang seirama dengan perkembangan bangsa Indonesia pada khususnya dan dunia pada umumnya. Perkembangan ini tentu saja membawa konsekuensi bahwa terbuka lapangan pekerjaan dibidang bisnis (Gitosudarmo, 2000). Para pengusaha memang sangat mendambakan manajemen bisnis dengan metode yang lebih baik.

Dalam memilih konsep bisnis dan metode bisnis yang digunakan, idealnya para pelaku bisnis atau suatu perusahaan harus mengkombinasikan antara faktor internal dan eksternal terutama sumber daya (resources) dan menganalisa sumber daya tersebut. Setelah menganalisa peluang dan ancaman 
dari faktor eksternal dan kemudian dapat memaksimalkan seluruh komponen sumber daya (resources) internal dengan menciptakan berbagai keunggulan, barulah kemudian menyiapkan strategistrategi untuk bisa mencapai tujuan. Strategi yang dimaksud adalah langkah perencanaan yang lebih terukur dan sistematis yang memiliki perbedaan dan ciri khas tersendiri baik dari sisi produk atau jasa yang dihasilkan maupun kompetensi dari sumber daya manusia (Uska, 2010).

Perencanaan strategis penting untuk memperoleh keunggulan bersaing (competitive advantage) (Rangkuty, 2003). Dalam aplikasinya perencanaan strategis yang baik dan matang akan berpengaruh pula market orientation. Melalui market orientation mengenai bagaimana pegaruhnya terhadap kinerja perusahaan mendorong perusahan berinovasi terhadap produknya dan bagaimana manajemen yang baik untuk memahami dengan benar apa yang menjadi keinginan dan kebutuhan konsumen. Kemampuan perusahaan untuk memahami keinginan dan kebutuhan konsumen dan menyediakan produk atau jasa yang diinginkan dan dibutuhkan konsumen dikenal dengan istilah market orientation (Naver dan Slater, 1990 dalam Alam, 2013). Fokus perusahaan terhadap market orientation merupakan strategi dan salah satu peran yang penting dalam aktivitas marketing. Sehingga perusahaan yang menggunakan metode market orientation akan semakin tinggi laba bersih, tentunya juga akan semakin bagus value perusahaan yang akan berpengaruh pada kinerja perusahaan.

Menurut Slater dan Narver (1990), dalam Esteban et al, (2002) untuk dapat menghasilkan superior value bagi pelanggan dengan efisien dan efektif maka diperlukan perusahaan yang ber-market orientation. Market orientation didefinisikan sebagai budaya organisasi yang diperlukan seluruh elemen dalam perusahaan agar selalu memperoleh informasi tentang kebutuhan pelanggan baik kebutuhan saat ini maupun kebutuhan potensial yang memungkinkan timbul di masayang akan datang. Peningkatan market orientation selain akan mempengaruhi kinerja perusahaan melalui tingkat kepuasan pelanggan, juga dapat meningkatkan komitmen organisasi karyawan (Kohli dan Jaworski, 1990).

Dalam market orientation terdapat 2 (dua) pendekatan yaitu pendekatan skala MARKOR (Kohli dan Jaworski, 1990) dan skala MKTOR (Narver dan Slater, 1990). Skala MARKOR adalah market orientation sebagai pengumpulan secara luas intelejen pasar yang berkaitan dengankebutuhan pelanggan sekarang atau kebutuhan pelanggan dimasa mendatang, penyebarluasan intelejen diantara departemendepartemen, respon dan organisasi terhadap intelejen tersebut. Sedangkan Skala MKTOR adalah market orientation yang terdiri atas orientasi pelanggan, orientasi pesaing, dan koordinasi antar fungsi. Market orientation pada skala MARKOR memantau dan menganalisis informasi yang menjadi keinginan dan kebutuhan pelanggan. Setelah itu mengimplementasikan informasi yang telah di dapat. Kemudian bagaimana respon perusahaan dan konsumen terhadap suatu produk atau jasa. Tidak jauh berbeda dengan MARKOR, skala MARKOR yaitu orientasi pelanggan dimana perusahaan berupaya menggali apa yang diinginkan pelanggan yang diharapkan loyalitas konsumen tercipta. Kemudian pemahaman akan kekuatan, kelemahan serta manajemen mengenali konsumen. Setelah itu koordinasi antar fungsi mengidentifikasi kemampuan yang dibutuhkan organisasi dalam rangka membentuk rantai nilai yang meliputi aktivitas -aktivitas organisasi perusahaan.

Dari penelitian terdahulu yang dilakukan oleh Steriani Tulenan (2016) tentang "Orientasi Pasar pada UD Bintang Lima kacang telur di Kota Tomohon" menyimpulkan bahwa market orientation dikatakan baik dalam orientasi pelanggan yaitu pemahaman terhadap keinginan pelanggan, kepuasan serta menciptakan nilai bagi pelanggan. Dalam orientasi pesaing, UD merespon tindakan pesaing, menangkap peluang keunggulan bersaing, dan berusaha meningkatkan dan menemukan strategi untuk melawan pesaingnya. Sedangkan dalam koordinasi antar fungsi, para pekerja berkontribusi pada strategi UD dan penciptaan nilai pelanggan, saling bekerja sama antar pekerja, dan untuk memahami kebutuhan pelanggan sehingga tercipta kepuasan bagi pelanggan.

Dari uraian tersebut penulis tertarik melaksanakan penelitian tentang "market orientation pada PT Gunung Hijau Masarang berdasarkan skala MARKOR". Penelitian ini akan berpengaruh bagaimana kinerja perusahaan berdasarkan skala markor serta perusahaan harus membuat komitmen jangka panjang untuk mempertahankan hubungan melalui kualitas, pelayanan, dan inovasi. Konsekuensinya, market orientation telah menjadi prasyarat bagikesuksesan dan kemampuan untuk menghasilkan keuntungan (profitability) bagi setiap perusahaan (Jaworski \& Kohli 1990).

\section{Rumusan Masalah}

Berdasarkan latar belakang tersebut, maka perumusan masalah adalah bagaimana market orientation pada PT Gunung Hijau Masarang yang terdiri atas intelejensi pasar, penyebarluasan intelejensi pasar, responsivitas intelegensi pasar.

\section{Tujuan Penelitian}

Penelitian ini bertujuan untuk mengetahui market orientation yang terdiri atas intelejensi pasar, penyebarluasan intelejensi pasar, dan responsivitas atas intelegensi pasar. Untuk menguji dan menganalisis 
pengumpulan intelejensi pasar, penyebarluasan Intelejensi pasar, dan responsivitas atas intelegensi pasar.

\section{Manfaat Penelitian}

1. Bagi peneliti dapat melatih cara berpikir serta menganalisis data, dan penelitian ini merupakan salah satu syarat untuk memperoleh gelar sarjana di Fakultas Pertanian Universitas Sam Ratulangi Manado.

2. Bagi pihak perusahaan, diharapakan dapat menjadi bahan pertimbangan dalam menentukan kebijakan dalam mempertahankan dan meningkatkan kinerja bisnis perusahaan.

3. Bagi peneliti lain ataupun pembaca, dapat dijadikan bahan referensi untuk penelitian yang serupa.

\section{METODE PENELITIAN}

\section{Waktu dan Tempat penelitian}

Penelitian ini dilaksanakan selama 3 (tiga) bulan yaitu pada bulan Mei 2017 sampai Juli 2017 mulai dari persiapan sampai penyusunan laporan penelitian. Tempat penelitian adalah di PT Gunung Hijau Masarang yang ada di Kelurahan Tondangouw Kecamatan Tomohon Selatan, Kota Tomohon.

\section{Teknik Pengumpulan Data}

Data yang diperlukan untuk penelitian ini adalah data primer, yang berhubungan dengan pengukuran market orientation yang terdiri dari 3 kelompok dengan 32 item pernyataan. Data primer yang dikumpulkan bersifat kualitatif yang dikuantifikasikan dengan menggunakan skala Likert dengan range antara 1 (satu) sampai dengan 5 (lima). Kuantifiaksi diperlukan untuk mendukung proses analisis. Pengumpulan data yang dilakukan dalam penelitian ini, yaitu observasi dan wawancara. Observasi dilakukan dengan pengamatan langsung pada PT Gunung Hijau Masarang yang berada di Kelurahan Tondangouw, kecamatan Tomohon Selatan, Kota Tomohon, sedangkan wawancara bertujuan untuk mendapatkan informasi secara langsung tentang market orientation perusahaan.

Target responden adalah kesluruhan populasi dalam penelitian ini adalah semua karyawan yang berjumlah 20 (dua puluh) orang dengan rincian 1 (satu) orang direktur, 1 (satu) orang manajer pemasaran, 1 (satu) orang manajer produksi, 3 (tiga) orang karyawan administratif 3 (tiga) orang bagian personalia, 3 (tiga) orang bagian operasional 3 (tiga) orang bagian loket, 2 (dua) orang bagian pembibitan tanaman pohon aren dan 3 (tiga) orang bagian pengawas dan supervisor pohon aren, namun dibatasi sebanyak 6 (enam) orang sebagai keterwakilan karena kebijakan perusahaan. Pengambilan data dilakukan dengan menggunakan daftar pernyataandan menanyakan langsung kepada 6 (enam) orang responden dalam perusahaan yaitu direktur 1 (satu) orang, manager 2 (dua) orang, karyawan-karyawan 3 (tiga) orang.

\section{Konsep Variabel Penelitian}

Variabel dalam penelitian ini dikembangkan dari Kohli dan Jaworski (1990) yang terdiri dari Intelgensi Pasar terdiri dari 10 item pernyataan, Penyebaran Integensi Pasar terdiri dari 8 (delapan) item penyataan dan Responsivitas intelegensi pasar terdiri dari 14 (empat belas) item pernyataan.

A. Intelejensi pasar

1. Pelayanan kebutuhan konsumen.

2. Metode dalam melayani konsumen.

3. Riset pemasaran in-house.

4. Intelegensi perubahan preferensi konsumen.

5. Survey penilaian mutu produk.

6. Intelegensi terhadap pengaruh pembelian produk.

7. Pengumpulan informasi tentang industri.

8. Pengumpulan informasi tentang pesaing.

9. Intelgensi mengenai kompetisi teknologi dan regulasi konsumen.

10. Pengkajian secara periodik perubahan dampak lingkungan bisnis.

B. Penyebaran intelgensi pasar

1. Perbincangan informal tentang taktik atau strategi pesaing.

2. Pertemuan formal mengenai pengembangan tren pasar.

3. Diskusi tentang kebutuhan konsumen.

4. Mensirkulasikan dokumen-dokumen secara periodik mengenai informasi konsumen.

5. Kecepatan informasi tentang konsumen utama.

6. Menginformasikan kepuasan konsumen pada semua level perusahaan.

7. Komunikasi manajer pemasaran dan produksi tentang perkembangan pasar.

8. Kecepatan informasi mengenai tindakan pesaing.

C. Responsivitas intelgensi pasar

1. Respon terhadap perubahan harga produk pesaing.

2. Segmentasi pasar dalam pengembangan produk.

3. Respon terhadap perubahan kebutuhan konsumen terhadap produk.

4. Evaluasi pengembangan produk.

5. Perencanaan bisnis yang berorientasi kemajuan teknologi dibanding riset pasar.

6. Menanggapi perubahan di lingkungan bisnis.

7. Produk yang tergantung politik internal dibandingkan kebutuhan pasar.

8. Respon atas preferensi konsumen.

9. Aktivitas perusahaan terkoordinasi dengan baik. 
10. Respon perusahaan mengenai komplain konsumen.

11. Rencana pemasaran secara tepat waktu.

12. Responsivitas terhadap perubahan harga pesaing.

13. Tindakan korektif mengenai mutu produk.

14. Respon atas keinginan konsumen pada inovasi produk.

\section{Skala Pengukuran}

Skala yang digunakan akan digunakan dalam penyusunan kuisioner adalah menggunkan skala Likert, yaitu untuk mengukur sikap, pendapat dan persepsi seseorang atau sekelompok orang tentang fenomena. Dalam penelitian ini akan dianalisis skala MARKOR dengan menggunakan skala likert pada setiap item. Untuk keperluan analisis kuantitatif, maka jawaban kuisioner diberi skor sebagai berikut : $1=$ sangat tidak setuju; $2=$ tidak setuju; $3=$ Netral $4=$ setuju; 5= sangat setuju.

\section{Analisis Data}

Dalam penelitian ini analisis data yang digunakan adalah analisis data deskriptif dengan menggunakan skala Likert. Dalam penelitian ini diketahui market orientation berdasarkan skala MARKOR. Setelah itu disusun pertanyaan dan diberikan kepada responden. Jawaban setiap instrumen menggunakan skala Likert yang berupa kata-kata, antar lain

$\begin{array}{lll}\text { SS } & =\text { Sangat Setuju } & \text { Skor }=5 \\ \text { S } & =\text { Setuju } & \text { Skor }=4 \\ \text { N } & =\text { Netral } & \text { Skor }=3 \\ \text { TS } & =\text { Tidak Setuju } & \text { Skor }=2 \\ \text { STS } & =\text { Sangat Tidak Setuju } & \text { Skor }=1\end{array}$
pernyataan

Dengan cara perhitungan skor masing - masing Jumlah skor setiap kriterium $=$ capaian skor $\mathrm{X}$ jumlah responden

$$
\begin{aligned}
& \text { S5 }=5 \times 6=30 \\
& \text { S } 4=4 \times 6=24 \\
& \text { S } 3=3 \times 6=18 \\
& \text { S2 }=2 \times 6=12 \\
& \text { S1 }=1 \times 6=6
\end{aligned}
$$

Jumlah skor ideal untuk setiap pernyataan $($ skor tertinggi $)=30$

Jumlah skor terendah $=7$

\begin{tabular}{|c|c|c|c|c|}
6 & 12 & 18 & 24 & 30 \\
\hline STS & TS & N & S & SS
\end{tabular}

Cara perhitungan skor keseluruhan untuk mengetahui market orientation

Jumlah skor seluruh kriterium = capaian jumlah skor $\mathrm{X}$ jumlah responden $\mathrm{X}$ instrumen pernyataan

$$
\begin{aligned}
& \text { S5 }=5 \times 6 \times 32=960 \\
& \text { S4 }=4 \times 6 \times 32=768 \\
& \text { S3 }=3 \times 6 \times 32=576
\end{aligned}
$$

$$
\mathrm{S} 2=2 \times 6 \times 32=384
$$

$\mathrm{S} 1=1 \times 6 \times 32=192$

Jumlah skor ideal keseluruhan untuk keseluruhan pernyataan $=960$ (tertinggi)

Jumlah skor rendah $=192$

\begin{tabular}{|c|c|c|c|c|}
$0 \%-20 \%$ & $20 \%-40 \%$ & $40 \%-60 \%$ & $60 \%-80 \%$ & $80 \%-100 \%$ \\
\hline STS & TS & N & S & SS
\end{tabular}

Tingkat market orientation $=\frac{\text { Jumlah Skor hasil pengumpulan data }}{\text { jumlah skor ideal (tertinggi) }} \times 100 \%$

Keterangan kriteria interpretasi skor market orientation (Riduwan, 2012)

Angka $\quad 0 \%-20 \% \quad$ Sangat Tidak Setuju.

Angka 20\%-40\% Tidak Setuju.

Angka $40 \%-60 \% \quad$ Netral.

Angka 60\%-80\% Setuju.

Angka 80\%-100\% Sangat Setuju.

\section{HASIL DAN PEMBAHASAN}

\section{Deskripsi Gula Aren dan Profil PT Gunung Hijau Masarang}

Gula aren atau biasa disebut dengan gula merah dihasilkan dari nira pohon Enau yang biasanya diolah oleh masyarakat biasanya dengan cara tradisional. Gula aren sudah dikenal dengan sejak lama masyarakat Indonesia. Gula aren yang dihasilkan dari bunga jantan pohon enau yang disimpan di bumbung bambu selama beberapa waktu sebelum diproduksi menajdi gula aren. Kemudian menghasilkan nira yang dimasak untuk mendapatkan gula aren asli dan terbaik. Gula Aren memiliki cita rasa yang sangat baik dibandingkan dengan gula biasa yang mengandung bahan pemutih gula atau dicampurkan pemanis buatan.

PT Gunung Hijau Masarang didirikan pada tahun 2007 yang terletak di kelurahan Toundangouw, kecamatan Tomohon Selatan kota Tomohon. PT Gunung Hijau Masarang merupakan unit perusahaan dari Yayasan Masarang. Perusahaan ini mengolah air nira (saguer dalam bahasa Manado) yang berasal dari pohon Enau menjadi gula aren. PT Gunung Hijau Masarang merupakan perusahaan yang melakukan produksi air nira menjadi gula kristal dengan memanfaatkan uap panas bumi sebagai bahan bakar. Pohon Aren rata-rata menghasilkan 17,2 liter nira per pohon per hari. Kandungan gula dari air nira yang dihasilkan berkisar $10 \%-17 \%$. 


\begin{abstract}
Intelegensi Pasar
a. Pelayananan Kebutuhan Konsumen

Pelayanan kepada konsumen bertujuan memelihara dan meningkatkan hubungan psikologis antara produsen dan konsumen serta memantau berbagai keluhan konsumen. Pelayanan yang memenuhi standar kualitas adalah suatu pelayanan yang sesuai dengan harapan dan kepuasan konsumen. Perusahaan memahami akan kebutuhan konsumen dengan baik melalui produk yang dibeli konsumen. Pada Tabel 2 menjelaskan tentang pelayanan kebutuhan konsumen.
\end{abstract}

Tabel 2. Hasil Penelitian Pelayanan Kebutuhan Konsumen

\begin{tabular}{lcccc}
\hline \multicolumn{1}{c}{ Altematif Jawaban } & $\begin{array}{c}\text { Altematif } \\
\text { Skor }\end{array}$ & Jumlah Responden & $\begin{array}{c}\text { Presentase } \\
\text { Responden }\end{array}$ & $\begin{array}{c}\text { Total } \\
\text { Skor }\end{array}$ \\
\hline Sangat Setuju & 5 & - & - & - \\
Setuju & 4 & 4 & 66,7 & 16 \\
Netral & 3 & 2 & 33,3 & 6 \\
Tidak Setuju & 2 & 1 & 16,7 & 2 \\
Sangat Tidak Setuju & 1 & - & - & - \\
\hline \multicolumn{1}{c}{ Total } & & 6 & 100 & 24
\end{tabular}

Sumber: Diolah dari data primer, 2017.

Hasil penelitian yang menunjukkan bahwa $66,7 \%$ responden memilih setuju terhadap pelayanan kebutuhan konsumen karena mereka melakukan kegiatan menemui konsumen seperti yang di lakukan oleh pihak yayasan masarang yang ada di Eropa dengan minimal setahun sekali. Sesuai dengan pernyataan yang terdapat pada rekapitulasi, angka indeks market orientation mengenai pelayanan kebutuhan konsumen yaitu $80 \%$ dengan interpretasi setuju karena menurut perusahaan terhadap pelayanan kebutuhan konsumen karena konsumen merupakan salah satu faktor penentu keberhasilan penjualan produk.

\section{b. Metode Dalam Melayani Konsumen}

Pelayanan konsumen (customer service) adalah bukan sekedar suatu keunggulan kompetitif. Beberapa perusahaan customer service adalah ujung tombak yang membuat suatu perusahaan bisa bertahan dalam persaingan bisnis yang semakin ketat. Perusahaan memiliki metode yang lebih baik dalam memberikan layanan yang dijelaskan pada Tabel 3 berikut.

\begin{tabular}{lcccc}
\multicolumn{6}{l}{ Tabel 3. Hasil Penelitian Metode dalam Melayani Konsumen. } \\
\hline \multicolumn{1}{c}{ Altematif Jawaban } & $\begin{array}{c}\text { Altematif } \\
\text { Skor }\end{array}$ & $\begin{array}{c}\text { Jumlah } \\
\text { Responden }\end{array}$ & $\begin{array}{c}\text { Presentase } \\
\text { Responden }\end{array}$ & $\begin{array}{c}\text { Total } \\
\text { Skor }\end{array}$ \\
\hline Sangat Setuju & 5 & 1 & 16,7 & 5 \\
Setuju & 4 & 2 & 33,3 & 8 \\
Netral & 3 & 3 & 50 & 9 \\
Tidak Setuju & 2 & - & - & - \\
Sangat Tidak Setuju & 1 & - & - & - \\
\hline \multicolumn{1}{c}{ Total } & & 6 & 100 & 22 \\
\hline
\end{tabular}

Sumber: Diolah dari data Primer, 2017

Hasil penelitian ini menunjukkan 16,7\% responden memilih sangat setuju. 33,3\% responden karena perusahaan ini melakukan metode melayani konsumen seperti mereka berinteraksi dengan konsumen dalam pelayanan kebutuhan konsumen. Angka indeks market orientation mengenai metode dalam melayani konsumen yaitu $73,3 \%$ setuju yang menunjukkan perusahaan melakukan metode dalam melayani konsumen, berinteraksi secara langsung dengan konsumen merupakan metode dalam melayani konsumen dalam perusahaan ini.

c. Riset Pemasaran In-House

Riset pemasaran salah satu kegiatan dibidang pemasaran yang dilakukan secara sitematis mulai dari perumusana masalah, tujuan penelitian, pengumpulan data, pengolahan data dari interpretasi hasil penelitian. Dalam Tabel 4 perusahaan melakukan riset pamasaran secara in-house atau secara mandiri.

Tabel 4. Hasil penelitian riset pemasaran in - house

\begin{tabular}{|c|c|c|c|c|}
\hline Altematif Jawaban & $\begin{array}{c}\text { Altematif } \\
\text { Skor }\end{array}$ & $\begin{array}{c}\text { Jumlah } \\
\text { Responden }\end{array}$ & $\begin{array}{l}\text { Presentase } \\
\text { Responden }\end{array}$ & $\begin{array}{l}\text { Total } \\
\text { Skor }\end{array}$ \\
\hline Sangat Setuju & 5 & 2 & 33,3 & 10 \\
\hline Setuju & 4 & 3 & 50 & 12 \\
\hline Netral & 3 & 1 & 16,6 & 3 \\
\hline Tidak Setuju & 2 & - & - & - \\
\hline Sangat Tidak Setuju & 1 & - & - & - \\
\hline Total & & 6 & 100 & 25 \\
\hline
\end{tabular}

Hasil penelitian menunjukkan bahwa 33,3\% responden memilih sangat setuju dan 50\% responden menjawab setuju karena mereka melaksanakan dengan mempercayakan bagian pemasaran yang ada di beberapa Negara di benua Eropa dan Singapura dalam hal ini bagian dari yayasan masarang untuk melakasanakan riset pemasaran. Sesuai dengan pernyataan yang terdapat pada rekapitulasi, angka indeks market orientation pemasaran secara in house yaitu $83,3 \%$ yang menunjukkan bahwa riset pemasaran secara in-house mendapat hasil interpretasi sangat setuju yang berarti perusahaan berupaya malaksanakan riset untuk mengetahui aspek-aspek terkait dengan produk yang dihasilkan kepada konsumen.

d. Intelegensi Perubahan Preferensi Konsumen

Preferensi konsumen dapat berarti kesukaan, pilihan atau sesuatu hal yang lebih disukai konsumen. Preferensi ini terbentuk dari persepsi konsumen terhadap produk seseorang selalu dapat membuat atau menyusun rangking semua situasi/kondisi mulai dari yang paling disenangi hingga yang paling tidak disukai. Pada Tabel 5 perusahaan ingin mengetahui tentang perubahan preferensi pelanggan.

\begin{tabular}{|c|c|c|c|c|}
\hline Altematif Jawaban & $\begin{array}{l}\text { Alternatif } \\
\text { Skor }\end{array}$ & $\begin{array}{c}\text { Jumlah } \\
\text { Responden }\end{array}$ & $\begin{array}{l}\text { Presentase } \\
\text { Responden }\end{array}$ & $\begin{array}{l}\text { Tota } \\
\text { Skor }\end{array}$ \\
\hline Sangat Setuju & 5 & - & - & - \\
\hline Setuju & 4 & - & - & - \\
\hline Netral & 3 & - & - & - \\
\hline Tidak Setuju & 2 & 4 & 66,7 & 8 \\
\hline Sangat Tidak Setuju & 1 & 2 & 33,3 & 2 \\
\hline Total & & 6 & 100 & 10 \\
\hline
\end{tabular}

Hasil penelitian menunjukkan $66,7 \%$ menjawab tidak setuju dan $33,3 \%$ menajawab sangat tidak setuju karena perusahaan memahami dengan baik kebutuhan konsumen. Seperti perusahaan langsung mengetahui apa yang di butuhkan konsumen melalui riset 
pemasaran in-house (mandiri). Menurut perusahaan juga sesuai dengan pernyataan yang terdapat pada rekapitulasi, angka indeks yang diukur dari intelegensi perubahan preferensi konsumen mendapat interpretasi $33,3 \%$ yang berarti mereka tidak setuju dengan penyataan perusahaan termasuk lambat dalam mendeteksi perubahan-perubahan preferensi pelanggan. Perusahaan baik dalam melihat dan menanggapi perubahan preferensi konsumen.

\section{e. Survey Penilaian Mutu Produk}

Mutu merupakan istilah yang mempunyai makna berbeda bagi setiap orang. Perusahaan ini melakukan survey penilaian mutu produk kepada pengguna akhir dengan baik yang dilaksanakan minimal sekali dalam setahun. Pada Tabel 6 Perusahaan memahami penilaian mutu produk dengan baik.

\begin{tabular}{|c|c|c|c|c|}
\hline Altematif Jawaban & $\begin{array}{c}\text { Altematif } \\
\text { Skor }\end{array}$ & $\begin{array}{c}\text { Jumlah } \\
\text { Responden }\end{array}$ & $\begin{array}{l}\text { Presentase } \\
\text { Responden }\end{array}$ & $\begin{array}{l}\text { Total } \\
\text { Skor }\end{array}$ \\
\hline Sangat Setuju & 5 & 2 & 33,3 & 10 \\
\hline Setuju & 4 & 3 & 66,7 & 12 \\
\hline Netral & 3 & 1 & 16,7 & 3 \\
\hline Tidak Setuju & 2 & - & - & - \\
\hline Sangat Tidak Setuju & 1 & - & - & - \\
\hline Total & & 6 & 100 & 25 \\
\hline
\end{tabular}

Sumber: Diolah dari data Primer, 2017

Hasil penelitian ini menunjukkan bahwa $33,3 \%$ responden menjawab sangat setuju dan 66,7 responden menjawab setuju survey penilaian mutu produk. Perusahaan merespon dengan baik jika ada produk yang rusak seperti perusahaan langsung menarik produk yang rusak dan mengganti dengan yang baru.Perusahaan juga mengakaji kembali produk sebelum di pasarkan dan memeriksa mutu produk yang sesuai dengan standaryang baik.Sesuai dengan pernyataan yang terdapat pada rekapitulasi angka indeks interpretasi mengenai survey penilaian mutu produk mendapat interpretasi dengan nilai $83,3 \%$ yang menunjukkan bahwa perusahaan ini sangat setuju terhadap penilaian mutu produk karena menurut perusahaan ketika mutu produk kurang baik akan berpengaruh terhadap penjualan.

f. Intelegensi Terhadap Pengaruh Pembelian Produk

Keputusan pembelian merupakan tindakan yangnyata dan bukan suatu tindakan saja, tetapi terdiri dari beberapa tindakan yang meliputi keputusan tentang jenis produk, merek, harga, kuaalitas, kuantitas, waktu pembelian dan cara pembayarannya. Kemampuan perusahaan ingin mengetahui tentang pengaruh pembelian produk oleh konsumen dapat dijelaskan pada Tabel 7 berikut.
Tabel 7. Hasil Penelitian Intelegensi Terhadap Pengaruh Pembelian Produk

\begin{tabular}{lcccc}
\hline Altematif Jawaban & $\begin{array}{c}\text { Altematif } \\
\text { Skor }\end{array}$ & $\begin{array}{c}\text { Jumlah } \\
\text { Responden }\end{array}$ & $\begin{array}{c}\text { Presentase } \\
\text { Responden }\end{array}$ & $\begin{array}{c}\text { Total } \\
\text { Skor }\end{array}$ \\
\hline Sangat Setuju & 5 & 2 & 33,3 & 10 \\
Setuju & 4 & 2 & 33,3 & 8 \\
Netral & 3 & - & - & - \\
Tidak Setuju & 2 & 2 & 33,3 & 4 \\
Sangat Tidak Setuju & 1 & - & - & - \\
\hline \multicolumn{2}{c}{ Total } & 6 & 100 & 22 \\
\hline Sumber: Diolah dari data primer, 2017. & & &
\end{tabular}

Hasil penelitian menunjukkan bahwa $33 \%$ menjawab sangat setuju dan setuju. Saat konsumen membeli produk gula PT Gunung Masarang berpengaruh terhadap kinerja pemasaran pada khususnya dan kinerja perusahaan pada umumnya. Sedangkan 33,3\% responden menjawab dengan responden menjawab tidak setuju tentang intelegensi terhadap pengaruh pembelian produk. Karena menurut reponden yang menanggapi dengan tidak setuju. Menurut perusahaan bahwa pesaing saat ini belum berpengaruh terhadap keputusan konsumen membeli gula aren. Sesuai dengan pernyataan yang terdapat pada rekapitulasi angka indeks interpretasi mengenai intelegensi pengaruh pembelian produk terhadap gula Aren Masarang mendapat nilai $73,3 \%$ yang berarti sangat setuju terhadap pengumpulan intelegensi tentang pesaing yang menunjukkan bahwa pembelian produk untuk mencari tahu seberapa besar potensi dan pengaruh terhadap produk yang dibeli.

\section{g. Pengumpulan Informasi Tentang Industri}

Informasi mengenai industri berpengaruh terhadap bagaimana perusahaan mempunyai inovasi sebagai strategi bersaing perusahaan. Strategi tersebut dikembangkan melalui proses perencanaan atau mungkinmelalui kegiatan-kegiatan dari berbagai departemen fungsional perusahaaan. Perusahaan ini melakukan pengumpulan informasi tentang industri dengan baik yang ditunjukkan pada Tabel 8 berikut.

\begin{tabular}{|c|c|c|c|c|}
\hline Altematif Jawaban & $\begin{array}{l}\text { Alternatif } \\
\text { Skor }\end{array}$ & $\begin{array}{c}\text { Jumlah } \\
\text { Responden }\end{array}$ & $\begin{array}{l}\text { Presentase } \\
\text { Responden }\end{array}$ & $\begin{array}{l}\text { Total } \\
\text { Skor }\end{array}$ \\
\hline Sangat Setuju & 5 & 2 & 33,3 & 10 \\
\hline Setuju & 4 & 1 & 16,7 & 4 \\
\hline Netral & 3 & 3 & 50 & 9 \\
\hline Tidak Setuju & 2 & - & - & - \\
\hline Sangat Tidak Setuju & 1 & - & - & - \\
\hline Total & & 6 & 100 & 23 \\
\hline
\end{tabular}

Hasil menunjukkan terdapat $33,3 \%$ responden menjawab sangat setuju dan $16,7 \%$ menjawab setuju mengenai hal ini. Perusahaan mengumpulkan informasi mengenai industri seperti mencari informasi yang berhubungan dengan industri dengan menggunakan media internet atau pembicaraan secara informal misalnya saat istirahat makan siang karena pengumpulan informasi mengenai industri dapat mengetahui mengenai potensi dan peluang serta kelemahan dan ancaman baik lingkungan internal dan eksternal perusahaan. Sesuai dengan pernyataan yang terdapat dalam rekapitulasi angka indeks interpretasi pengumpulan informasi mengenai industri mendapat angka $90 \%$ yang berarti sangat setuju, yang 
menunjukkan bahwa perusahaan mengumpulkan informasi untuk mengetahui sejauh mana teknologi industri bergembang serta meng-upgrade teknologi ketika diperlukan.

\section{h. Pengumpulan Informasi tentang Pesaing}

Perusahaan mengenali pesaing dari sudut pandang pasar. Pesaing mungkin termasuk semua perusahaan atau usaha yang membuat produk yang memasok jasa yang sama. PT Gunung Hijau Masarang menetapkan pesaing sebagai perusahaan yang mencoba memuaskan kebutuhan pelanggan yang sama atau melayani kelompok pelanggan yang sama. Perusahaan melakukan pengumpulan informasi tentang pesaing dan hasilnya dijelaskan dalam Tabel 9 berikut.

Tabel 9. Hasil Penelitian Pengumpulan Informasi tentang Pesaing

\begin{tabular}{|c|c|c|c|c|}
\hline Alternatif Jawaban & $\begin{array}{c}\text { Altematif } \\
\text { Skor }\end{array}$ & $\begin{array}{c}\text { Jumlah } \\
\text { Responden }\end{array}$ & $\begin{array}{l}\text { Presentase } \\
\text { Responden }\end{array}$ & $\begin{array}{l}\text { Total } \\
\text { Skor }\end{array}$ \\
\hline Sangat Setuju & 5 & 2 & 33,3 & 10 \\
\hline Setuju & 4 & 3 & 50 & 12 \\
\hline Netral & 3 & 1 & 16,7 & 3 \\
\hline Tidak Setuju & 2 & - & - & - \\
\hline Sangat Tidak Setuju & 1 & - & - & - \\
\hline Total & & 6 & 100 & 25 \\
\hline
\end{tabular}

Hasil Penelitian diatas menunjukkan bahwa $33,3 \%$ responden 2 (dua) orang menjawab sangat setuju dan $50 \%$ responden menjawab setuju pengumpulan informasi tentang pesaing. Sampai saat ini menurut perusahaan belum ada pesaing yang mempengaruhi mengenai kinerja perusahaan dalam hal ini market orientation. Namun perusahaan tetap melakukan intelegensi apa saja yang berpotensi mengancam kinerja perusahaan. Sesuai dengan pernyataan yang terdapat dalam rekapitulasi, angka indeks interpretasi mengenai pengumpulan informasi tentang pesaing mendapat angka $83,3 \%$ yang berarti sangat setuju yang menunjukkan bahwa perusahaan mengumpulkan informasi tentang pesaing sepertidengan cara mandiri atau riset pemasaran inhouse.

\section{i. Intelegensi mengenai Kompetensi Teknologi}

Saat ini teknologi semakin berkembang dan tidak dapat dibendung. Teknologi mendorong perusahaan terus berinovasi pada produk untuk memenuhi kebutuhan dan keinginan pelangganya. Hal ini berdampak pada perusahaan masarang mengenai kompetensi teknologi dan regulasi konsumen yang ditunjukkan pada Tabel 10 berikut.

\begin{tabular}{lcccc}
\multicolumn{6}{l}{ Tabel 10. Hasil Penelitian Informasi tentang Kompetensi Teknologi } \\
\hline \multicolumn{1}{c}{ Altematif Jawaban } & $\begin{array}{c}\text { Altematif } \\
\text { Skor }\end{array}$ & $\begin{array}{c}\text { Jumlah } \\
\text { Responden }\end{array}$ & $\begin{array}{c}\text { Presentase } \\
\text { Responden }\end{array}$ & $\begin{array}{c}\text { Total } \\
\text { Skor }\end{array}$ \\
\hline Sangat Setuju & 5 & - & - & - \\
Setuju & 4 & - & - & - \\
Netral & 3 & 1 & 16,7 & 1 \\
Tidak Setuju & 2 & 1 & 16,7 & 2 \\
Sangat Tidak Setuju & 1 & 4 & 66,7 & 4 \\
\hline \multicolumn{1}{c}{ Total } & & 6 & 100 & 7 \\
\hline
\end{tabular}

Sumber: Diolah dari data primer, 2017
Hasil penelitian menunjukkan bahwa $16,7 \%$ responden menyatakan tidak setuju, sedangkan $66,7 \%$ responden sangat tidak setuju mengenai hal ini. Karena menurut mereka hal ini belum berpengaruh terhadap produk perusahaan saat ini. Perusahaan juga tetap mengikuti perekembangan informasi teknologi. Sesuai dengan pernyataan yang terdapat dalam rekapitulasi, angka indeks interpretasi mengenai pengumpulan informasi tentang pesaing mendapat angka 23,3\% yang berarti sikap perusahaan akan hal ini tidak setuju. Perusahaan berupaya mengikuti perkembangan informasi konsumen dan bisnis serta perkembangan teknologi.

\section{j. Pengkajian periodik perubahan dampak lingkungan bisnis}

Perubahan lingkungan bisnis akan terjadi setiap saat, umumnya berupa gerak perubahan dari salah satu gabungan faktor lingkungan luar perusahaan. Perusahaan ini melakukan pengkajian perubahan dampak lingkungan bisnis secara perodik dengan baik yang dibuktikan dengan hasil penelitian dalam Tabel 11 berikut.

Tabel 1l. Pengkajian Periodik Perubahan Dampak Lingkungan Bisnis

\begin{tabular}{|c|c|c|c|c|}
\hline Altematif Jawaban & $\begin{array}{l}\text { Altematif } \\
\text { Skor }\end{array}$ & $\begin{array}{c}\text { Jumlah } \\
\text { Responden }\end{array}$ & $\begin{array}{l}\text { Presentase } \\
\text { Responden }\end{array}$ & $\begin{array}{l}\text { Total } \\
\text { Skor }\end{array}$ \\
\hline Sangat Setuju & 5 & 1 & 16,7 & 5 \\
\hline Setuju & 4 & 4 & 66,7 & 16 \\
\hline Netral & 3 & 1 & 50 & 3 \\
\hline Tidak Setuju & 2 & - & - & - \\
\hline Sangat Tidak Setuju & 1 & - & - & - \\
\hline Total & & 6 & 100 & 24 \\
\hline
\end{tabular}

Hasil penelitian menunjukkan bahwa $16,7 \%$ responden menjawab sangat setuju dan $83,3 \%$ responden menjawab setuju tentang pengkajian periodik perubahan dampak lingkungan bisnis. Perusahaan melakukan hal ini dalam rapat formal secara rutin yaitu setiap pekan. Sesuai dengan pernyataan yang terdapat dalam rekapitulasi, angka indeks interpretasi mengenai pengkajian periodik perubahan dampak lingkungan bisnis mendapat angka $83,3 \%$ yang artinya sangat setuju yang menunjukkan bahwa perusahaanberupaya menghadapi berbagai perubahan dan dinamika yang akan terjadi di masa mendatang yang dapat berupa ancaman maupun peluang demi mendapatkan profit yang besar sekaligus meningkatkan kepuasan pelanggan dan tentunya menjaga kelangsungan hidup perusahaan.

\section{k. Rekapitulasi Market orientation pada Intelegensi Pasar}

Rekapitulasi adalah ringkasan isi atau ikhtisiar pada akhir laporan atau akhir hitungan. Dari hasil perhitungan seluruh variabel pada market orientation dalam intelegensi pasar maka rekapitulasinya terdapat dalam Tabel 12 berikut. 


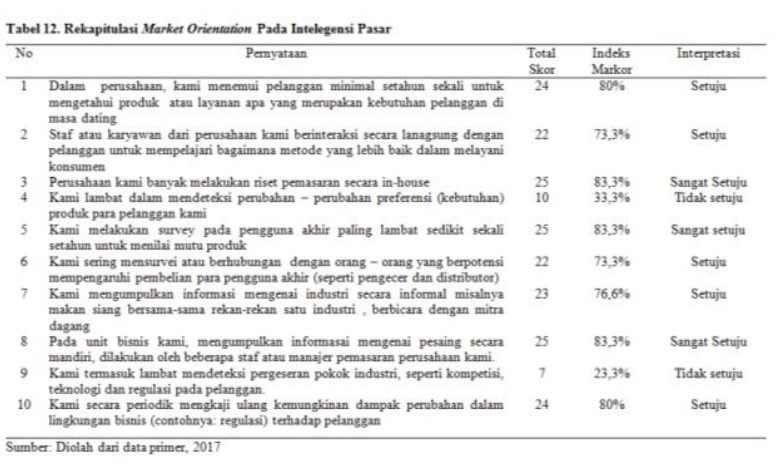

Tabel 12 menunjukkan market orientation pada intelegensi pasar dimana pernyataan dengan interpretasi sangat setuju yaitu pada pernyataan 1, 2, 6, 7, 10. Pernyataan Tidak setuju terdapat pada pernyataan 4 dan 9 . Pernyataan sangat setuju terdapat pada pernyataan 3 , 5, dan 8 dimana pernyataan ini merupakan indeks MARKOR yang paling tinggi yaitu $83,3 \%$ sedangkan untuk indeks MARKOR yang paling rendah terdapat pada pernyataan 9 dengan indeks MARKOR 23,3\%.

\section{Penyebarluasan Intelegensi Pasar}

a. Perbincangan Informal tentang taktik atau Strategi Pesaing

Menyusun strategi berarti mencari jalan bagaimana mencapai hasil yangditargetkan sesuai dengan visi dan misi di dalam situasi organisasi dan prospekyang dihadapi. Perusahaan ini melaksanakan perbincangan taktik atau strategi pesaing sekalipun dengan cara informal yang dibuktikan dengan hasil penelitian pada Tabel 13 berikut.

\begin{tabular}{|c|c|c|c|c|}
\hline Altematif Jawaban & $\begin{array}{l}\text { Altematif } \\
\text { Skor }\end{array}$ & $\begin{array}{c}\text { Jumlah } \\
\text { Responden }\end{array}$ & $\begin{array}{l}\text { Presentase } \\
\text { Responden }\end{array}$ & $\begin{array}{l}\text { Total } \\
\text { Skor }\end{array}$ \\
\hline Sangat Setuju & 5 & - & - & - \\
\hline Setuju & 4 & 3 & 50 & 12 \\
\hline Netral & 3 & 1 & 16,7 & 3 \\
\hline Tidak Setuju & 2 & 2 & 33,3 & 4 \\
\hline Sangat Tidak Setuju & 1 & - & - & - \\
\hline Total & & 6 & 100 & 19 \\
\hline
\end{tabular}

Sumber: Diolah dari data Primer, 2017

Hasil penelitian menunjukkan bahwa 50\% responden menjawab setuju dengan ini yang artinya meskipun perbincangan secara informal mengenai taktik atau strategi pesaing dalam rapat formal perusahaan hal itu berpengaruh terhadap perkembangan perusahaan seperti kinerja pemasaran, dan $33,3 \%$ responden bersikap tidak setuju yang menunjukkan bahwa hal ini seharusnya diperbincangakan secara formal. Sesuai dengan pernyataan yang terdapat dalam rekapitulasi, angka indeks interpretasi mengenai perbincangan informal taktik dan strategi pesaing mendapat angka 63,3\% yang berarti setuju, menujukkan bahwa dalam perusahaan saat waktu tertentu seperti saat makan siang atau break melakukan perbincangan secara informal.

\section{b. Pertemuan Formal Mengenai Pengembangan Tren Pasar \\ Dalam menjalankan sebuah bisnis maka juga} perlu melakukan perkembangan pasar yang menjadi tren atau banyak diminati oleh konsumen. Dimana sampai saat ini pasar merupakan faktor utama yang penting dan dibutuhkan oleh para pelaku bisnis dalam bidang apapun. Perusahaan harus melakukan sebuah tindakan agar mampu mengatasi tren pasar yang berubah-ubah agar tetap memberikan kelancaran bagi bisnis yang dijalankan misalnya melakukan sebuah pertemuan formal yang didalamnya membicarakan mengenai tren pasar dalam Tabel 14 berikut.

\begin{tabular}{|c|c|c|c|c|}
\hline Altematif Jawaban & $\begin{array}{l}\text { Altematif } \\
\text { Skor }\end{array}$ & $\begin{array}{c}\text { Jumlah } \\
\text { Responden }\end{array}$ & $\begin{array}{l}\text { Presentase } \\
\text { Responden }\end{array}$ & $\begin{array}{l}\text { Total } \\
\text { Skor }\end{array}$ \\
\hline Sangat Setuju & 5 & 2 & 33,3 & 10 \\
\hline Setuju & 4 & 3 & 66,7 & 12 \\
\hline Netral & 3 & 1 & 16,7 & 3 \\
\hline Tidak Setuju & 2 & - & - & - \\
\hline Sangat Tidak Setuju & 1 & - & - & - \\
\hline Total & & 6 & 100 & 25 \\
\hline
\end{tabular}

Hasil penelitian menunjukkan bahwa $33,3 \%$ responden menjawab sangat setuju dan $66,7 \%$ responden setuju mengenai diskusi tentang kebutuhan konsumen baik secara informal seperti saat istirahaat makan ataupun saat coffee break maupun secara formal dalam rapat. Menurut perusahaan ini diskusi tentang kebutuhan konsumen begitu penting karena memenuhi akan kebutuhan konsumen konsumen menjadi nilai tambah perusahaan.Sesuai dengan pernyataan yang terdapat dalam rekapitulasi, angka indeks interpretasi mengenai diskusi tentang kebutuhan konsumen mendapat angka $83,3 \%$ yang menunjukkan sikap perusahaan sangat setuju, yang ditunjukkan oleh perusahaan bahwa mereka secara berkala mengadakan rapat untuk membicarakan pengembangan tren pasar.

c. Diskusi tentang Kebutuhan Konsumen

Dalam Tabel 2 dalam item pelayanan akan kebutuhan konsumen meunjukkan hasil yang baik dimana angka indeks markor presentasenya adalah $80 \%$ yang berarti setuju. Sehingga dalam dalam item berikut ini diskusi tentang kebutuhan konsumen yang diaplikasikan oleh perusahaan dalam diskusi menunjukkan baik dalam ini yang dijelaskan dalam Tabel 15 berikut.

\begin{tabular}{|c|c|c|c|c|}
\hline Alternatif Jawaban & $\begin{array}{l}\text { Altematif } \\
\text { Skor }\end{array}$ & $\begin{array}{c}\text { Jumlah } \\
\text { Responden }\end{array}$ & $\begin{array}{l}\text { Presentase } \\
\text { Responden }\end{array}$ & $\begin{array}{l}\text { Total } \\
\text { Skor }\end{array}$ \\
\hline Sangat Setuju & 5 & 3 & 50 & 15 \\
\hline Setuju & 4 & 3 & 50 & 12 \\
\hline Netral & 3 & - & - & - \\
\hline Tidak Setuju & 2 & - & - & - \\
\hline Sangat Tidak Setuju & 1 & - & - & - \\
\hline Total & & 6 & 100 & 27 \\
\hline
\end{tabular}

Sumber: Diolah dari data Primer, 2017

Hasil penelitian menunjukkan bahwa $50 \%$ responden menjawab sangat setuju dan $50 \%$ responden 
setuju mengenai diskusi tentang kebutuhan konsumen baik secara informal seperti saat istirahat makan ataupun saat coffee break maupun secara formal dalam rapat. Menurut perusahaan diskusi tentang kebutuhan konsumen begitu penting karena memenuhi akan kebutuhan konsumen menjadi hal yang berpengaruh dalam market orientation perusahaan. Sesuai dengan pernyataan yang terdapat dalam rekapitulasi, angka indeks interpretasi mengenai diskusi tentang kebutuhan konsumen mendapat angka $90 \%$ yang menunjukkan sikap perusahaan sangat setuju yang ditunjukkan perusahaan adalah manajer/staf pemasaran membicarakan berdiskusi informal ataupun formal mengenai informasi pelanggan.

d. Mensirkulasikan Dokumen-dokumen

Secara Periodik mengenai Informasi konsumen

Informasi mengenai konsumen dalam bentuk dokumen - dokumen, salah satu kunci kemajuan suatu perusahaan atau bisnis adalah kemampuan memanfaatkan informasi dari pelanggan. Perusahaan ini melakukannya dengan baik yang ditunjukkan pada hasil penelitian dalam Tabel 16 berikut.

Tabel 16. Mensirkulasikan Dokumen-dokumen Secara Periodik mengenai

\begin{tabular}{lcccc}
\multicolumn{2}{c}{ Informasi konsumen } & & & \\
\hline \multicolumn{1}{c}{ Altematif Jawaban } & $\begin{array}{c}\text { Altematif } \\
\text { Skor }\end{array}$ & $\begin{array}{c}\text { Jumlah } \\
\text { Responden }\end{array}$ & $\begin{array}{c}\text { Presentase } \\
\text { Responden }\end{array}$ & $\begin{array}{c}\text { Total } \\
\text { Skor }\end{array}$ \\
\hline Sangat Setuju & 5 & 1 & 16,7 & 5 \\
Setuju & 4 & 4 & 66,7 & 16 \\
Netral & 3 & 1 & 16,7 & 3 \\
Tidak Setuju & 2 & - & - & - \\
Sangat Tidak Setuju & 1 & - & - & - \\
\hline \multicolumn{1}{c}{ Total } & & 6 & 100 & 26 \\
\hline
\end{tabular}

Sumber: Diolah dari data primer, 2017

Hasil penelitian menunjukkan bahwa $16,7 \%$ responden bersikap sangat setuju sedangkan 66,7\% responden bersikap setuju karena perusahan melaksanakan sirkulasi dokumen guna menegetahui mengenai informasi konsumen. Kegiatan yang dilakukan perusahaan penggunaan informasi lewat sirkulasi dokumen dilakukan oleh perusahaan seperti mereka mengumpulkan dokumen - dokumen mengenai konsumen yang dilaksanakan oleh pihak yayasan di Eropa. Sesuai dengan pernyataan yang terdapat dalam rekapitulasi, angka indeks interpretasi adalah 86,6\% yang berarti perusahaan ini bersikap sangat setuju akan hal ini. Perusahaan mengumpulkan dokumen untuk mencari tahu informasi penting mengenai data penjualan produk.

\section{e. Kecepatan Informasi Tentang Konsumen}

Informasi tentang konsumen dapat membantu perusahaan memahami akan kebutuhan konsumen, memudahkan penawaran produk, menentukan waktu dan bentuk interaksi yang disukai konsumen. Perusahaan ini mampu mendapatkan informasi menegenai konsumen yang ditunjukkan oleh hasil penelitian pada Tabel 17 berikut.
Tabel 17. Kecepatan Informasi Tentang konsumen

\begin{tabular}{lcccc}
\hline \multicolumn{1}{c}{ Altematif Jawaban } & $\begin{array}{c}\text { Altematif } \\
\text { Skor }\end{array}$ & $\begin{array}{c}\text { Jumlah } \\
\text { Responden }\end{array}$ & $\begin{array}{c}\text { Presentase } \\
\text { Responden }\end{array}$ & $\begin{array}{c}\text { Total } \\
\text { Skor }\end{array}$ \\
\hline Sangat Setuju & 5 & 4 & 66,7 & 20 \\
Setuju & 4 & 2 & 33,3 & 8 \\
Netral & 3 & - & - & - \\
Tidak Setuju & 2 & - & - & - \\
Sangat Tidak Setuju & 1 & - & - & - \\
\hline \multicolumn{1}{c}{ Total } & & 6 & 100 & 28 \\
\hline Sul & & & &
\end{tabular}

Sumber: Diolah dari data Primer, 2017

Hasil penelitian menunjukkan bahwa $66,7 \%$ responden menjawab dengan sangat setuju dan 33,3\% responden menjawab setuju mengenai kecepatan informasi mengenai konsumen. Menurut perusahaan ini kecepatan informasi merupakan salah satu strategi yang dapat mengetahui tentang kebutuhan dan keinginan konsumen terhadap suatu produk. Informasi yang cepat dapat membantu perusahaan memperbaiki apa yang keliru terhadap strategi bersaing mereka. Sesuai dengan pernyataan yang terdapat dalam rekapitulasi, angka indeks interpretasi mengenai kecepatan informasi mengenai konsumen mendapat angka 93,3\% yang menunjukkan sikap perusahaan sangat setuju yang ditunjukkan oleh perusahaan, perusahaan mendapatkan informasi tentang konsumen melalui pelayanan kebutuhan konsumen.

f. Menginformasikan kepuasan Konsumen kepada semua Level Unit Bisnis dalam Perusahaan

Secara umum kepuasan dapat diartikan sebagai suatu perbandingan antaralayanan atau hasil yang diterima konsumen dengan harapan konsumen, layanan atau hasilyang diterima itu paling tidak harus sama dengan harapan konsumen, atau bahkan melebihinya. Perusahaan ini menginformasikan kepuasan konsumen di semua level unit bisnis dalam perusahaan yang ditunjukkan pada hasil penelitian Tabel 18 berikut.

$\begin{aligned} & \text { Tabel 18. Menginformasikan Kepuasan Konsumen } \\
& \text { Bisnis dalam Perusahaaan } \\
& \end{aligned}$
\begin{tabular}{lccccc}
\multicolumn{1}{c}{ Altematif Jawaban } & $\begin{array}{c}\text { Altematif } \\
\text { Skor }\end{array}$ & $\begin{array}{c}\text { Jumlah } \\
\text { Responden }\end{array}$ & $\begin{array}{c}\text { Presentase } \\
\text { Responden }\end{array}$ & $\begin{array}{c}\text { Total } \\
\text { Skor }\end{array}$ \\
\hline Sangat Setuju & 5 & 2 & 33,3 & 10 \\
Setuju & 4 & 3 & 66,7 & 12 \\
Netral & 3 & 1 & 16,7 & 3 \\
Tidak Setuju & 2 & - & - & - \\
Sangat Tidak Setuju & 1 & - & - & - \\
\hline \multicolumn{1}{c}{ Total } & & 6 & 100 & 25 \\
\hline
\end{tabular}

Sumber: Diolah dari data Primer, 2017

Hasil penelitian menunjukkan bahwa $33,3 \%$ responden menjawab sangat setuju dan $66,7 \%$ menjawab setuju mengenai menginformasikan kepuasan konsumen di semua level unit bisnis dalam perusahaan seperti yang dilakukandalam rapat formal perusaahaan. Setiap staf perusahaan memiliki kesempatan untuk memberikan informasi mengenai pelanggan tentang kepuasan pelanggan terhadap produk. Menurut perusahaan ini mengkomunikasikan mengenai kepuasan konsumen terhadap suatu produk berpengaruh positif terhadap citra perusahaan. Sesuai dengan pernyataan yang terdapat dalam rekapitulasi, 
angka indeks interpretasi mengenai menginformasikan kepuasan konsumen di semua level unit bisnis dalam perusahaan mendapat angka $83,3 \%$ yang menunjukkan sikap perusahaan terhadap hal ini sangat setuju yang ditunjukkan oleh perusahaan mengenai data pelanggan di distribusikan kepada seluruh karyawan perusahaan.

g. Komunikasi Manajer pemasaran dan produksi tentang perkembangan pasar

Komunikasi meruapakan hal yang penting dalam organisai perusahaan. Perusahaan melaksanakan komunikasi antara manajer pemasaran dan produksi untuk membicarakan mengenai perkembangan pasar yang ditunjukkan pada Tabel 19 berikut ini.

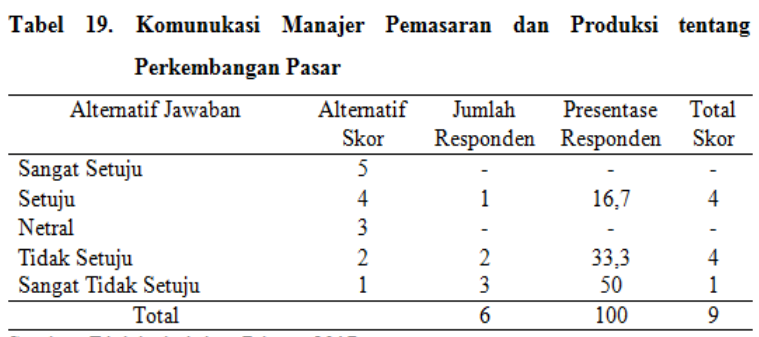

Sumber: Diolah dari data Primer, 2017

Hasil penelitian menunjukkan bahwa $16,7 \%$ responden menjawab setuju yang berarti bahwa komunikasi manajer pemasaran dan produksi berpengaruh pada pengaruh perubahan pasar terhadap teknologi, pengaruh teknologi terhadap penciptaaan dan pengembangan inovasi produk, dimana sesuai dengan standar keinginan konsumen. Sedangkan 33,3 $\%$ responden dan $50 \%$ responden 3 (tiga) orang menjawab sangat tidak setuju karena sesuai dengan pernyataan bahwa "komunikasi manjer pemasaran dan produksi mengenai perkembangan pasar berlangsung minimal" menurut mereka komunikasi ini tetap berlangsung pada setiap rapat formal ataupun saat sedang istirahat makan siang atau break. Sesuai dengan pernyataan yang terdapat dalam rekapitulasi, angka indeks interpretasi mendapat angka $30 \%$ yang menunjukkan sikap tidak setuju bahwa perusahaan didalamnya manajer pemasaran dan produksi melakukan komunikasi berlangsung minimal. Penyataan ini bersifat negatif, menurut perusahaan diskusi informal berlangsung dengan baik dan secara formal berlangsung secara berkala.

h. Kecepatan Informasi tentang Tindakan
Pesaing
Agar dapat menetapkan strategi pemasaran kompetitif yang efektif, perusahaan harus memperoleh semua informasi tentang para pesaingnya. Dalam pernyataan "ketika karyawan atau staf menemukan informasi yang penting mengenai pesaing, staf atau karyawan terlamabat menyampaikan kepada manajer. Kecepatan informasi tentang tindakan pesaing ditunjukkan pada hasil penelitian pada Tabel 20 berikut.
Tabel 20. Kecepatan Informasi tentang Tindakan Pesaing

\begin{tabular}{lcccc}
\hline \multicolumn{1}{c}{ Altematif Jawaban } & $\begin{array}{c}\text { Alternatif } \\
\text { Skor }\end{array}$ & $\begin{array}{c}\text { Jumlah } \\
\text { Responden }\end{array}$ & $\begin{array}{c}\text { Presentase } \\
\text { Responden }\end{array}$ & $\begin{array}{c}\text { Total } \\
\text { Skor }\end{array}$ \\
\hline Sangat Setuju & 5 & - & - & - \\
Setuju & 4 & - & - & - \\
Netral & 3 & - & - & - \\
Tidak Setuju & 2 & 3 & 50 & 6 \\
Sangat Tidak Setuju & 1 & 3 & 50 & 3 \\
\hline \multicolumn{1}{c}{ Total } & & 6 & 100 & 9 \\
\hline
\end{tabular}

Sumber: Diolah dari data Primer, 2017

Hasil penelitian menunjukkan bahwa 50\% menjawab tidak setuju dan $50 \%$ resoponden menjawab sangat tidak setuju karena menurut perusahaan, mereka langsung menanggapi jika ada sesuatu yang begitu penting mengenai pesaing. Perusahaan mngupayakan dalam mencari informasi sesuai dengan fakta di lapangan misalnya saat pengumpulan informasi tentang pesaing. Sesuai dengan pernyataan yang terdapat dalam rekapitulasi, angka indeks interpretasi mendapat angka $30 \%$ yang berarti perusahaan ini tidak setuju terhadap keterlambatan informasi menegenai pesaing. Penyataan ini bersifat negatif, menurut perusahaan mereka mengkomunikasikan dengan manajer.

i. Rekapitulasi Market Orientation pada

Penyebarluasan Intelegensi Pasar

Rekapitulasi adalah ringkasan isi atau ikhtisiar pada akhir laporan atau akhir hitungan. Dari hasil perhitungan seluruh variabel pada market orientation dalam penyebarluasan intelegensia pasar maka rekapitulasinya ditunjukksn pada Tabel 21 berikut.

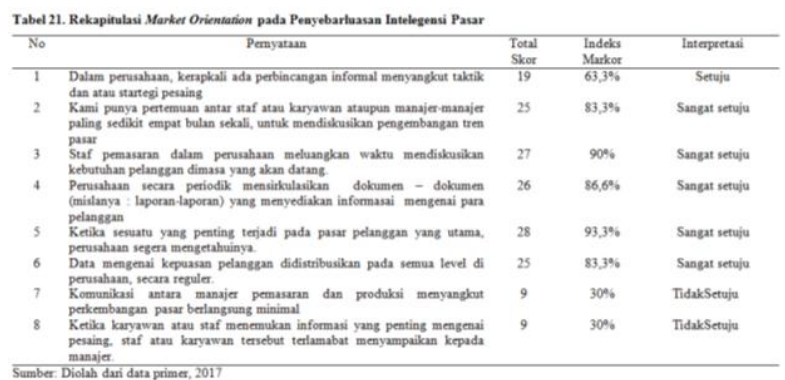

Tabel 21 menunjukkan bahwa pernyataan 2, 3, 4, 5, 6 adalah interpretasi sangat setuju. Pernyataan dengan interpretasi setuju terdapat pada pernyataan 1, sedangkan untuk pernyataan 7 dan 8 adalah interpretasi tidak setuju dan yang paling terendah dengan indeks MARKOR $30 \%$. Indeks MARKOR tertinggi terdapat pada penyataan 3 dengan indeks MARKOR $90 \%$.

\section{Responsivitas Atas Intelegensi Pasar}

a. Respon Terhadap Perubahan Harga Produk Pesaing

Dalam dunia usaha atau bisnis, kehadiran pesaing sering kali menguntungkan, namun juga bisa merugikan. Pesaing akan menguntungkan jika kedatangannya membuat pasar di wilayah penjualan menjadi besar. Ini artinya, dengan berkumpulnya pesaing, menjadi pusat atau sentra bisnis tertentu sehingga menjadi rujukan para konsumen untuk 
datang.Sesuai dengan pernyataan yang terdapat dalam lampiran perusahaan ini melakukan respon terhadap perubahan harga produk pesaing yang ditunjukkan pada Tabel 22 berikut.

\begin{tabular}{|c|c|c|c|c|}
\hline Altematif Jawaban & $\begin{array}{l}\text { Alternatif } \\
\text { Skor }\end{array}$ & $\begin{array}{c}\text { Jumlah } \\
\text { Responden }\end{array}$ & $\begin{array}{l}\text { Presentase } \\
\text { Responden }\end{array}$ & $\begin{array}{l}\text { Total } \\
\text { Skor }\end{array}$ \\
\hline Sangat Setuju & 5 & - & - & - \\
\hline Setuju & 4 & - & - & \\
\hline Netral & 3 & 1 & 16,7 & 3 \\
\hline Tidak Setuju & 2 & 5 & 83,3 & 10 \\
\hline Sangat Tidak Setuju & 1 & - & - & - \\
\hline Total & & 6 & 100 & 14 \\
\hline
\end{tabular}

Hasil penelitian menunjukkan bahwa $83,3 \%$ responden menjawab tidak setuju mengenai tindakan tersebut, karena perusahaan ini melaksanakan respondengan baik. Seperti mereka langsung berdiskusi dalam rapat formal perusahaan terhadap pengambilan keputusan terhadap perubahan harga pesaing dengan cepat, karena keputusan yang cepat terhadap perubahan harga pesaing berpengaruh terhadap keputusan pembelian produk oleh konsumen. Sesuai dengan pernyataan yang terdapat dalam rekapitulasi, angka indeks interpretasi mendapat angka $40 \%$ yang berarti perusahaan bersikap tidak setuju terhadap hal ini karena perusahaan berupaya untuk tidak membuat keputusan yang lama menanggapi perubahan produk pesaing.

\section{b. Segmentasi Pasar sebagai Pengembangan Produk}

Segmentasi pasar adalah proses dimana pasar dibagi menjadi para pelanggan yang terdiri atas orangorang dengan berbagai kebutuhan dan karakteristik yang sama, mengarahkan mereka untuk merespon tawaran produk atau jasa dan program pemasaran strategis tertentu dalam cara yang sama. Perusahaan ini melakukan segmentasi pasar dalam pengembangan produk yang ditunjukkan pada Tabel 23 berikut.

\begin{tabular}{lcccc}
\multicolumn{6}{l}{ Tabel 23. Segmentasi Pasar dalam Pengembangan Produk } \\
\hline \multicolumn{1}{c}{ Altematif Jawaban } & $\begin{array}{c}\text { Alternatif } \\
\text { Skor }\end{array}$ & $\begin{array}{c}\text { Jumlah } \\
\text { Responden }\end{array}$ & $\begin{array}{c}\text { Presentase } \\
\text { Responden }\end{array}$ & $\begin{array}{c}\text { Total } \\
\text { Skor }\end{array}$ \\
\hline Sangat Setuju & 5 & 1 & 16,7 & 5 \\
Setuju & 4 & 3 & 50 & 12 \\
Netral & 3 & 2 & 33,3 & 6 \\
Tidak Setuju & 2 & - & - & - \\
Sangat Tidak Setuju & 1 & - & - & - \\
\hline \multicolumn{2}{c}{ Total } & 6 & 100 & 23 \\
\hline Sumber: Diolah dari data Primer, 2017 & & &
\end{tabular}

Hasil penelitian menunjukkan bahwa $16,7 \%$ responden menyikapi setuju dan $50 \%$ responden menanggapi dengan setuju akan hal ini karena menurut perusahaan mereka melaksanakan dalam mendesain program-program pemasaran yang baik sesuai dengan kebutuhan konsumen. Seperti mereka membuat produk dari gula aren berupa jus yang dapat dinikmati oleh anak-anak maupunorang dewasa. Sesuai dengan pernyataan yang terdapat dalam rekapitulasi, angka indeks interpretasi mendapat angka 76,6\% yang berarti perusahaan ini menyikapi dengan setuju terhadap segmentasi pasar dalam pengembangan produk disesuaikan dengan prinsip untuk memenuhi kebutuhan konsumen.

c. Respon terhadap Perubahan Kebutuhan Konsumen terhadap Produk

Respon atau reaksi terhadap kebutuhan konsumen merupakan fokus yang harus dipenuhi dalam pemasaran. Mulai dari desain produk penentuan harga, hingga saluran distribusi semua dirancang untuk memenuhi kebutuhan konsumen. Dalam pernyataan perusahaan menyikapi ini yang ditunjukkan pada Tabel 24 berikut.

Tabel 24. Respon Terhadap Perubahan Kebutuhan Konsumen Terhadap Produk

\begin{tabular}{lcccc}
\hline \multicolumn{1}{c}{ Altematif Jawaban } & $\begin{array}{c}\text { Altematif } \\
\text { Skor }\end{array}$ & $\begin{array}{c}\text { Jumlah } \\
\text { Responden }\end{array}$ & $\begin{array}{c}\text { Presentase } \\
\text { Responden }\end{array}$ & $\begin{array}{c}\text { Total } \\
\text { Skor }\end{array}$ \\
\hline Sangat Setuju & 5 & - & - & - \\
Setuju & 4 & - & - & - \\
Netral & 3 & - & - & - \\
Tidak Setuju & 2 & 4 & 66,7 & 8 \\
Sangat Tidak Setuju & 1 & 2 & 33,3 & 2 \\
\hline \multicolumn{1}{c}{ Total } & & 6 & 100 & 10 \\
\hline
\end{tabular}

Sumber: Diolah dari Data Primer, 2017

Hasil penelitian menunjukkan bahwa $66,7 \%$ responden menjawab tidak setuju dan $33,3 \%$ responden menjawab sangat tidak setuju, karena perusahaan mengutamakan akan kebutuhan konsumen untuk semua alasan dengan tidak terkecuali. Seperti pelayanan yang baik pada konsumen dalam hal ini respon jika ada konsumen yang mendapati jika produk kadaluarsa ataupun mengandung unsur logam sehingga perusahaan harus merespon, karena tindakan ini berdampak pada seluruh manajemen perusaahaan dalam pemasaran maupun produksi. Sesuai dengan pernyataan yang terdapat dalam rekapitulasi, angka indeks interpretasi mendapat angka $33,3 \%$ yang berarti perusahaan ini tidak setuju dengan pernyataan ini bahwa perusahaan ingin berupaya untuk tidak mengabaikan perubahan kebutuhan konsumen.

d. Evaluasi Pengembangan Produk

Pengembangan produk merupakan serangkaian aktivitas yang dimulai dari analisis persepsi dan peluang pasar, kemudian diakhiri dengan tahap produksi, penjualan, dan pengiriman produk (Ulrich dan Steven, 2001:2). Perusahaaan ini melakukan evaluasi pengembangan produk yang ditunjukkan pada Tabel 25 berikut.

Tabel 25. Evaluasi Pengembangan Produk

\begin{tabular}{lcccc}
\hline \multicolumn{1}{c}{ Altematif Jawaban } & $\begin{array}{c}\text { Altematif } \\
\text { Skor }\end{array}$ & $\begin{array}{c}\text { Jumlah } \\
\text { Responden }\end{array}$ & $\begin{array}{c}\text { Presentase } \\
\text { Responden }\end{array}$ & $\begin{array}{c}\text { Total } \\
\text { Skor }\end{array}$ \\
\hline Sangat Setuju & 5 & 2 & 33,3 & 10 \\
Setuju & 4 & 3 & 50 & 12 \\
Netral & 3 & - & - & - \\
Tidak Setuju & 2 & 1 & 16,7 & 2 \\
Sangat Tidak Setuju & 1 & - & - & - \\
\hline \multicolumn{1}{c}{ Total } & & 6 & 100 & 24 \\
\hline Sumber: Diolah dari Data Primer, 2017 & & & &
\end{tabular}


Hasil penelitian menunjukkan bahwa 33,3\% responden menjawab sangat setuju dan $50 \%$ responden menjawab setuju karena evaluasi dalam pengembangan produk perusahaan mengadakan riset dan pengembangan resmi, memilih ide dari karyawan mereka, dan mengadakan tukar pikiran dalam rapat eksekutif. Ide lain datang dari sumber eksternal. Dengan mengadakan survei dan kelompok fokus serta menganalisis pertanyaan dan keluhan pelanggan, perusahaan dapat menghasilkan ide produk baru yang akan memenuhi kebutuhan spesifik konsumen. Sedangkan 16,7\% menanggapi dengan tidak setuju hal ini. Sesuai dengan pernyataan yang terdapat dalam rekapitulasi, angka indeks interpretasi mendapat angka $80 \%$ yang berarti sikap perusahaan terhadap hal ini menunjukkan sikap sangat setuju karena perusahaan setiap selesai memproduksi 1 (satu) kloter gula aren mereka melaksanakan evaluasi pengembangan produk.

e. Perencanaan Bisnis yang Berorientasi

Kemajuan Teknologi dibanding Riset Pasar

Riset pasar banyak di lakukan bagi orang orang yang ingin memulai bisnis di suatu tempat. Manfaat riset pemasaran ini bertujuan untuk mengetahui minat pembelian barang atau produk di tempat usaha akan dijalankan. Demikian juga dengan kemajuan teknologi yang mempunyai peranan penting di dalam dunia bisnis terutama di bidang pemasaran. Peranan teknologi dalam bidang pemasaran yaitu menunjang kegiatan-kegiatan yang saling berhubungan dan ditujukan untuk merencanakan, menentukan harga, mempromosikan, serta mendistribusikan barang dan jasa kepada pembeli. Perusahaan ini melakukan menyikapi hal ini yang ditunjukkan pada Tabel 26 berikut.

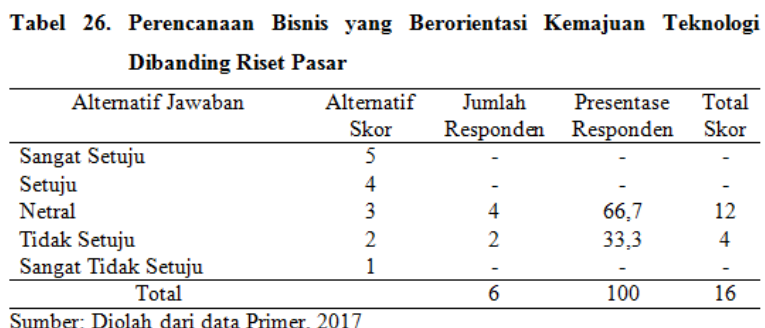

Hasil penelitian 33,3\% responden menjawab tidak setuju karena menurut mereka, riset pasar lebih memiliki peluang yang lebih besar dan manfaat seperi mencari pembeli, melihat pesaing, memanfaatkan pesaing, mengurangi resiko serta membangun potensi pasar. Sesuai dengan pernyataan yang terdapat dalam rekapitulasi, angka indeks interpretasi mendapat angka $53,3 \%$ yang berarti mereka menyikapi dengan netral akan hal ini.

f. Menanggapi Perubahan Lingkungan Bisnis

Setelah melaksanakan pengkajian perodik perubahan dampak lingkungan bisnis yang terjadi di luar perusahaan yang berpengaruh terhadap peluang lingkungan luar maupun di dalam perusahaan yang akan timbul dapat mempertajam peningkatan kualitas proses bisnis perusahaan. Sebaliknya sejauh mana kualitas proses bisnis suatu perusahaan akan terganggu dan menurun kualitasnya, jika potensi ancaman yang menghadang perusahaan dibiarkan begitu saja. Dalam hal ini bagaimana perusahaan menanggapi perubahan lingkungan bisnis di luar perusahaan yang ditunjukkan Tabel 27 berikut.

Tabel 27. Menanggapi Perubahan Lingkungan Bisnis

\begin{tabular}{lcccc}
\hline \multicolumn{1}{c}{ Altematif Jawaban } & $\begin{array}{c}\text { Altematif } \\
\text { Skor }\end{array}$ & $\begin{array}{c}\text { Jumlah } \\
\text { Responden }\end{array}$ & $\begin{array}{c}\text { Presentase } \\
\text { Responden }\end{array}$ & $\begin{array}{c}\text { Total } \\
\text { Skor }\end{array}$ \\
\hline Sangat Setuju & 5 & 3 & 50 & 15 \\
Setuju & 4 & 2 & 33,3 & 4 \\
Netral & 3 & 1 & 16,7 & 4 \\
Tidak Setuju & 2 & - & - & - \\
Sangat Tidak Setuju & 1 & - & - & - \\
\hline \multicolumn{1}{c}{ Total } & & 6 & 100 & 23 \\
\hline
\end{tabular}

Sumber: Diolah dari data Primer, 2017

Hasil penelitian menunjukkan 50\% responden menanggapi sangat setuju terhadap perubahan lingkungan bisnis dan 33,3\% responden menanggapi dengan setuju yang berarti menurut perusahaan, hal ini dapat menjadi tolak ukur yang lebih baik dalam menunjukkan kemana perusahaan berjalan dan seberapa baik menunjukkan perusahaan kinerja yang baik. Kemudian 33\% responden menjawab tidak setuju tentang tanggapan lingkngan bisnis karena menurut mereka belum terlalu berpengaruh terhadap lingkungan bisnis internal perusahaan. Sesuai dengan pernyataan yang terdapat dalam rekapitulasi, angka indeks interpretasi mendapat angka 76,6\% yang menunjukkan sikap perusahaan akan hal ini perusahan secara berkala merencanakan tindakan ketika terjadi perubahan lingkungan bisnis yang akan datang.

g. Aktivitas yang tergantung Politik Internal dibandingkan Kebutuhan Pasar

Kebutuhan adalah sesuatu yang muncul pada setiap pelanggan secara otomatis oleh karena kebutuhan itu melekat dengan pribadi manusia. Memenuhi kebutuhan dan keinginan konsumen lewat penjualan produk terhadap kebutuhan pasar menjadi salah satu syarat untuk mendaptkan nilai tambah suatu produk kepada konsumen. Memahami kebutuhan dan keinginan pasar berarti mengetahui apa yang sebenarnya akan dicari oleh konsumen. Usaha untuk ini bisa dilakukan dengan mengamati perilaku konsumen, mengamati perubahan lingkungan, atau memikirkan sesuatu yang baru sama sekali dan karena itu perusahaan memproduksi suatu produk yang tidak tergantung politik internal dalam perusahaan yang ditunjukkan pada Tabel 28 berikut 


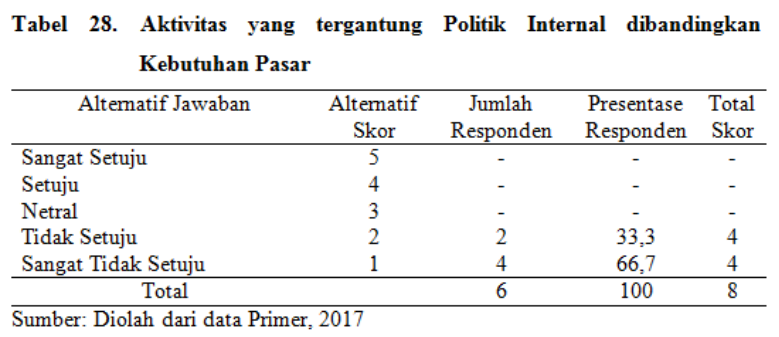

Hasil penelitian menunjukkan bahwa 33,3\% responden menjawab tidak setuju dan $66,7 \%$ responden menjawab sangat tidak setuju dengan adanya intervensi politik. Dalam perusahaan ini unsur politik tidak akan pernah diimplementasikan dalam hal ini kepentingan individu berdampak pada kinerja perusahaan. Sesuai dengan pernyataan yang terdapat dalam rekapitulasi, angka indeks interpretasi mendapat angka 26,6\% yang menunjukkan bahwa perusahaan tidak setuju mengenaipernyataan ini karena mereka menganggap hal ini tidak kompeten dan berpengaruh pada pemasaran.

\section{h. Respon atas Preferensi Konsumen}

Preferensi konsumen terhadap suatu produk berbeda - beda. Setiap konsumen dapat memilih sendiri apa yang disukainya sesuai dengan keinginan dan kebutuhannya. Respon terhadap preferensi konsumen berpengaruh terhadap mutu produk dan kinerja perusahaan. Pada Tabel 29 perusahaan memahami respon atas preferensi konsumen.

Tabel 29. Respon atas Preferensi Konsumen

\begin{tabular}{lcccc}
\hline \multicolumn{1}{c}{ Altematif Jawaban } & $\begin{array}{c}\text { Altematif } \\
\text { Skor }\end{array}$ & $\begin{array}{c}\text { Jumlah } \\
\text { Responden }\end{array}$ & $\begin{array}{c}\text { Presentase } \\
\text { Responden }\end{array}$ & $\begin{array}{c}\text { Total } \\
\text { Skor }\end{array}$ \\
\hline Sangat Setuju & 5 & 1 & 16,7 & 5 \\
Setuju & 4 & 5 & 83,3 & 20 \\
Netral & 3 & - & - & - \\
Tidak Setuju & 2 & - & - & - \\
Sangat Tidak Setuju & 1 & - & - & - \\
\hline \multicolumn{1}{c}{ Total } & & 6 & 100 & 25 \\
\hline
\end{tabular}

Sumber: Diolah dari data Primer, 2017

Hasil penelitian menunjukkan $16,7 \%$ responden menanggapi setuju dan 83,3 \% terhadap respon preferensi konsumen karena menurut perusahaan ini respon dalam hal pelayanan adalah kesempatan untuk mengoreksi masalah masalah yang mungkin belum pernah didengar perusahaan. Perusahaan melakukan respon seperti membuat menambah produk jus. Sesuai dengan pernyataan yang terdapat dalam rekapitulasi, angka indeks interpretasi mendapat angka 83,3\% yang menunjukkan sikap perusahaan setuju akan hal ini menunjukkan bahwa perusahaan berupaya untuk menanggapi konsumen ketika preferensi mereka kurang puas terhadap produk.

i. Aktivitas Perusahaan Terkoordinasi dengan Baik

Koordinasi merupakan salah salah satu fungsi manajemen yang memegang peranan sama penting dan setara dengan fungsi-fungsi manajemen lainnya, kesuksesan koordinasi akan menjamin keberhasilan pelaksanaan pekerjaan atau pencapaian tujuan organisasi. Koordinasi berarti mengikat, mempersatukan, dan menyelaraskan semua aktivitas dan usaha. Pemahaman yang baik atas koordinasi memungkinkan mampu dapat merencanakan dan melaksanakan aktivitas dengan baik. Perusahaan melakukan aktivitas yang terkoordinasi dengan baik yang ditunjukkan pada Tabel 30 berikut.

\begin{tabular}{|c|c|c|c|c|}
\hline Altematif Jawaban & $\begin{array}{c}\text { Altematif } \\
\text { Skor }\end{array}$ & $\begin{array}{c}\text { Jumlah } \\
\text { Responden }\end{array}$ & $\begin{array}{l}\text { Presentase } \\
\text { Responden }\end{array}$ & $\begin{array}{l}\text { Total } \\
\text { Skor }\end{array}$ \\
\hline Sangat Setuju & 5 & 2 & 33,3 & 15 \\
\hline Setuju & 4 & 3 & 50 & 12 \\
\hline Netral & 3 & 1 & 16,7 & 3 \\
\hline Tidak Setuju & 2 & - & - & - \\
\hline Sangat Tidak Setuju & 1 & - & - & - \\
\hline Total & & 6 & 100 & 30 \\
\hline
\end{tabular}

Hasil penelitian menunjukkan bahwa 33,3\% responden sangat setuju dan $50 \%$ bersikap setuju mengenai hal ini karena perusahaan melakukannya seperti manajer direktur melakukan pengawasan terhadap karyawan dan manajer operasional malakukan pengawasan terhadap produksi. Perusahaan menjalankan daftar hadir kepada seluruh karyawan dan pekerja.Sesuai dengan pernyataan yang terdapat dalam rekapitulasi, angka indeks interpretasi mendapatangka 90\% yang menyatakan sikap perusahaan sangat setuju akan hal inikarena berusaha untuk selalu melakanakan tugas tanggung jawab masing karyawanatau pekerja dan saling berkomunikasi.

\section{j. Respon Perusahaan Mengenai Komplain Konsumen}

Komplain pelanggan merupakan salah satu hal yang wajar terjadi. Baik dalam perusahaan atau usaha berskala kecil sampai dengan perusahaan berskala besar menerima komplain atau keluhan dari pelanggan. Sesuai dengan pernyataan "komplain pelanggan tidak ditanggapi diperusahaan ini" Perusahaan ini menanggapi pernyataan ini yang ditunjukkan pada Tabel 31 berikut.

\begin{tabular}{lcccc} 
Tabel 31. Respon Perusahaan Mengenai Komplain Konsumen \\
\hline \multicolumn{1}{c}{ Altematif Jawaban } & $\begin{array}{c}\text { Altematif } \\
\text { Skor }\end{array}$ & $\begin{array}{c}\text { Jumlah } \\
\text { Responden }\end{array}$ & $\begin{array}{c}\text { Presentase } \\
\text { Responden }\end{array}$ & $\begin{array}{c}\text { Total } \\
\text { Skor }\end{array}$ \\
\hline Sangat Setuju & 5 & - & - & - \\
Setuju & 4 & - & - & - \\
Netral & 3 & - & - & - \\
Tidak Setuju & 2 & 1 & 16,7 & 2 \\
Sangat Tidak Setuju & 1 & 5 & 83,3 & 5 \\
\hline \multicolumn{1}{c}{ Total } & & 6 & 100 & 7
\end{tabular}

Sumber: Diolah dari data Primer, 2017

Hasil penelitian menunjukkan bahwa $16,7 \%$ responden tidak setuju dengan hal ini dan 83,3\% responden menyatakan sangat tidak setuju karena Perusahaan memperhatikan hal - hal penting bagi konsumen, seperti saat produk mereka mngandung unsur logam mereka langsung melakukan penarikan terhadap produk gula aren. Sesuai dengan pernyataan yang terdapat dalam rekapitulasi, angka indeks interpretasi mendapat angka 23,3\% berarti perusahaan 
tidak setuju dengan pernyataan ini. Perusahaan merespon dengan baik ketika konsumen memberikan komplain.

\section{k. Rencana Pemasaran Secara Tepat Waktu}

Perencanaan memungkinkan perusahaan untuk membuat penilaian, mengenai pencapaian tujuan yang telah ditentukan dan melakukan koreksi untuk mencapai tujuan. Membuat rencana pemasaran dalam sebuah perusahaan sangatlah penting, kegiatan apapun tanpa melalui proses perencanaan akan sulit mendapatkan hasil yang baik atau memadai. Sesuai dengan pernyataan pemasaran secara tepat waktu yang dilakukan perusahaan dapat dilihat dari penjelasan Tabel 32 berikut.

Tabel 32. Rencana Pemasaran Secara Tepat Waktu

\begin{tabular}{lcccc}
\hline \multicolumn{1}{c}{ Altematif Jawaban } & $\begin{array}{c}\text { Altematif } \\
\text { Skor }\end{array}$ & $\begin{array}{c}\text { Jumlah } \\
\text { Responden }\end{array}$ & $\begin{array}{c}\text { Presentase } \\
\text { Responden }\end{array}$ & $\begin{array}{c}\text { Total } \\
\text { Skor }\end{array}$ \\
\hline Sangat Setuju & 5 & - & - & - \\
Setuju & 4 & - & - & - \\
Netral & 3 & - & - & - \\
Tidak Setuju & 2 & 3 & 50 & 6 \\
Sangat Tidak Setuju & 1 & 3 & 50 & 3 \\
\hline \multicolumn{1}{r}{ Total } & & 6 & 100 & 9 \\
\hline
\end{tabular}

Sumber: Diolah dari data Primer, 2017

Hasil penelitian menunjukkan bahwa mereka tidak setuju dengan jumlah responden $50 \%$ dan sangat tidak setuju 50\% responden yang menyatakan mereka melakukan pemasaran secara tepat waktu guna memenuhi kebutuahan konsumen. Sesuai dengan fakta yang ada di lapangan tidak sesuai dengan apa yang mereka harapakan. Rencana pemasaran secara tepat waktu yang telah mereka programkan terkendala karena masalah pengiriman seperti masalah cuaca saat distribusi barang. Sesuai dengan pernyataan yang terdapat dalam rekapitulasi, angka indeks interpretasi mendapat angka 30\% yang berarti perusahaan tidak setuju dengan pernyataan ini, bahwa perusahaan berupaya menerapkan secara tepat waktu pemasaran dan terkadang terkendala karena tepat waktu.

1. Responsivitas Terhadap Perubahan Struktur Harga Pesaing

Setelah mengembangkan struktur dan strategi penetapan harga, perusahaan sering kali menghadapi situasi yang memaksa mereka memelopori perubahan harga atau memberi respons terhadap perubahan harga oleh pesaing. Perusahan merespon terhadap perubahan harga pesaing yang yang ditunjukkan pada Tabel 33 berikut.

Tabel 33. Responsivitas terhadap Perubahan Harga Pesaing

\begin{tabular}{lcccc}
\hline \multicolumn{1}{c}{ Altematif Jawaban } & $\begin{array}{c}\text { Altematif } \\
\text { Skor }\end{array}$ & $\begin{array}{c}\text { Jumlah } \\
\text { Responden }\end{array}$ & $\begin{array}{c}\text { Presentase } \\
\text { Responden }\end{array}$ & $\begin{array}{c}\text { Total } \\
\text { Skor }\end{array}$ \\
\hline Sangat Setuju & 5 & 1 & $16,7 \%$ & 5 \\
Setuju & 4 & 4 & $83,3 \%$ & 20 \\
Netral & 3 & 1 & 16,7 & 3 \\
Tidak Setuju & 2 & - & - & - \\
Sangat Tidak Setuju & 1 & - & - & - \\
\hline \multicolumn{2}{c}{ Total } & 6 & 100 & 28 \\
\hline Sumber: Diolah dari data Primer, 2017 & & &
\end{tabular}

Hasil dari penelitian menunjukkan bahwa $16,7 \%$ responden menjawab sangat setuju dan $83,3 \%$ menjawab setuju karena responsivitas terhadap perubahan struktur harga pesaing perusahaan melakukan cara dengan mengurangi harga untukmenghargai pelanggan yang memberikan respons seperti membeli ataupun mempromosikan produk. Menyesuaikan harga agar ada perbedaan untuk pelanggan, produk, atau lokasi. Menyesuaikan harga untuk menawarkan kombinasi yang tepat dari mutu dan pelayanan dengan harga yang wajar menyesuaikan harga untuk memperhitungkan lokasi geografi pelanggan. Sesuai dengan pernyataan yang terdapat dalam rekapitulasi, angka indeks interpretasi mendapat angka 93,3\% yang berarti sikap perusahaan terhadap hal ini sangat setuju. Sikap setuju menunjukkan bahwa perusahaan menanggapi dengan baik perubahan strktur harga produk pesaing.

m. Tindakan Korektif Mengenai Mutu Produk

Kepuasan merupakan nilai yang dirasakan konsumen saat mengadakan pembelian suatu barang atau jasa. Kepuasan konsumen didefinisikan sebagai tanggapan pelanggan atas penilaian suatu jasa, dimana memberi tingkat hubungan konsumsiyang menyenangkan Tabel 34 berikut menunjukkan sikap perusahaan melakukan tindakan terhadap kepuasan konsumen.

Tabel 34. Tindakan Korektif Mengenai Mutu Produk

\begin{tabular}{lcccc}
\hline \multicolumn{1}{c}{ Altematif Jawaban } & $\begin{array}{c}\text { Altematif } \\
\text { Skor }\end{array}$ & $\begin{array}{c}\text { Jumlah } \\
\text { Responden }\end{array}$ & $\begin{array}{c}\text { Presentase } \\
\text { Responden }\end{array}$ & $\begin{array}{c}\text { Total } \\
\text { Skor }\end{array}$ \\
\hline Sangat Setuju & 5 & 5 & 83,3 & 25 \\
Setuju & 4 & 1 & 16,7 & 4 \\
Netral & 3 & - & - & - \\
Tidak Setuju & 2 & - & - & - \\
Sangat Tidak Setuju & 1 & - & - & - \\
\hline \multicolumn{1}{r}{ Total } & & 6 & 100 & 29 \\
\hline
\end{tabular}

Sumber: Diolah dari data Primer, 2017

Hasil penelitian menunjukkan 83,3\% menjawab sangat setuju dan $16,7 \%$ menjawab setuju terhadap tindakan ini karena hal ini bermanfaat bagi perusahaan sebagai indikator kemampuan berlaba perusahaan, khususnya sebagai pertimbangan dasar dalam perencanaan program pemasaran. Tindakan yang perusahaan lakukan adalah berdiskusi secara formal ataupun informal kemudian perusahaan memeriksa mutu produk yang telah diproduksi telah sesuai dengan kebutuhan konsumen. Sesuai dengan pernyataan yang terdapat dalam rekapitulasi, angka indeks interpretasi mendapat angka 96,6\% yang menunjukkan sikap perusahaan adalah sangat setuju. Perusahaan berupaya memperbaiki mutu produk ketika konsumen tidak merasa puas dengan mutu produk.

n. Respon atas Keinginan Pelanggan pada Inovasi Produk

Inovasi terpenting yang dapat dilakukan perusahaan adalah pembaharuan yang menyangkut produk itu sendiri, karena produk menjadi alasan utama seseorang untuk memilih dan membelinya. Konsumen 
akan membuat keputusan untuk membeli suatu produk apabila produk tersebut memiliki nilai lebih dibandingkan produk lainnya. Untuk menciptakan produk yang memiliki nilai jual dan daya saing yang tinggi, dalam proses inovasinya perusahaan harus dapat menciptakan strategi bisnis yang tepat. Tabel 35 berikut menunjukkan menunjukkan hasil mengenai respon terhadap keinginan pelanggan pada inovasi produk.

Tabel 35. Respon atas Keinginan Pelanggan pada Inovasi Produk

\begin{tabular}{lcccc}
\hline \multicolumn{1}{c}{ Altematif Jawaban } & $\begin{array}{c}\text { Altematif } \\
\text { Skor }\end{array}$ & $\begin{array}{c}\text { Jumlah } \\
\text { Responden }\end{array}$ & $\begin{array}{c}\text { Presentase } \\
\text { Responden }\end{array}$ & $\begin{array}{c}\text { Total } \\
\text { Skor }\end{array}$ \\
\hline Sangat Setuju & 5 & 2 & 33,3 & 10 \\
Setuju & 4 & 4 & 66,7 & 16 \\
Netral & 3 & - & - & - \\
Tidak Setuju & 2 & - & - & - \\
Sangat Tidak Setuju & 1 & - & - & - \\
\hline \multicolumn{1}{c}{ Total } & & 6 & 100 & 26 \\
\hline
\end{tabular}

Sumber: Diolah dari data Primer, 2017

Hasil penelitian menunjukkan bahwa 33,3\% responden menjawab sangat setuju dan $66,7 \%$ menjawab setuju mengenai hal ini karena respon pelanggan terhadap inovasi pengembangan produk sangat erat kaitannya dengan keberhasilan suatu perusahaan dalam usaha meningkatkan penjualannya perusahaan melakukan inovasi produk seperti jus. Sesuai dengan pernyataan yang terdapat dalam rekapitulasi, angka indeks interpretasi mendapat angka $86,6 \%$ yang menunjukkan sikap perusahaan sangat setuju terhadap hal ini, yang ditunjukkan oleh perusahan dengan selalu berupaya mencari informasi inovasi produk.

o. Rekapitulasi Market Orientation pada

Responsivitas atas Intelegensi Pasar

Rekapitulasi adalah ringkasan isi atau ikhtisiar pada akhir laporan atau akhir hitungan. Dari hasil perhitungan seluruh variabel pada responsivitas atas intelegensi pasar ditunjukkan pada Tabel 36 berikut.

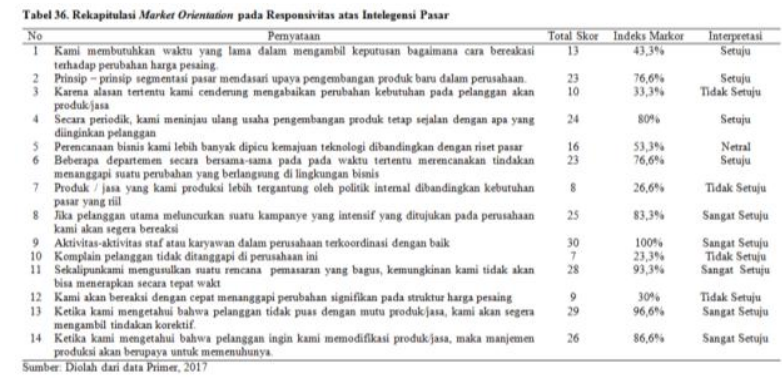

Tabel 36 menunjukkan terdapat 14 item pernyataan dalam market orientation pada responsivitas atas intelegensi pasar dimana interpretasi sangat setuju terdapat dalam pernyataan 8, 9, 11, 13 dan 14, sementara indeks markor yang tertinggi terdapat dalam pernyataan 9 dengan angka $100 \%$. Sedangkan interpretasi setuju terdapat pada pernyataan 1, 2,4 dan 6. Interpretasi netral terdapat dalam pernyataan 5 dengan indeks markor $53,3 \%$. Sedangkan interpretasi tidak setuju terdapat dalam pernyataan 3 ,
7, 10, dan 12. Nilai indeks yang paling rendah $23,3 \%$ terdapat dalam pernyataan nomor 10 .

\section{Hasil rekapitulasi Market Orientation pada PT. Gunung Hijau masarang}

Rekapitulasi adalah ringkasan isi atau ikhtisiar pada akhir laporan atau akhir hitungan. Dari hasil perhitungan seluruh variabel pada responsivitas atas intelegensi pasar ditunjukkan pada Tabel 37 berikut.

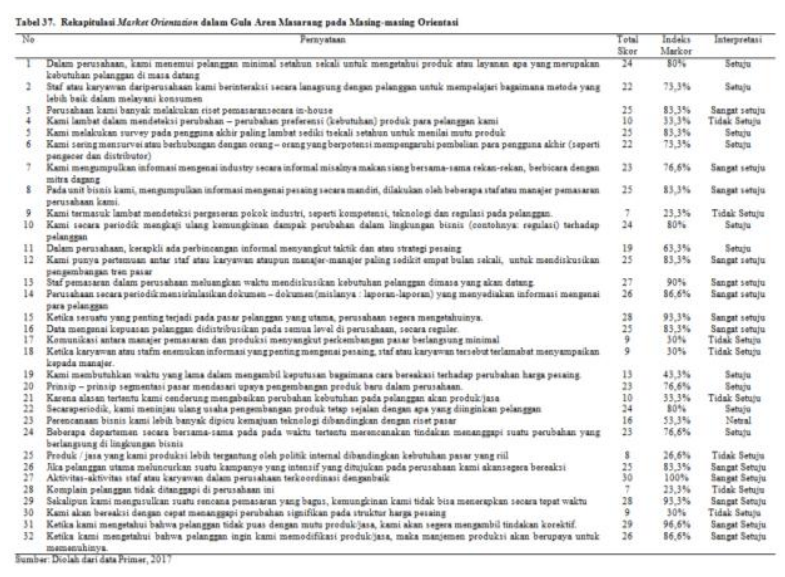

Untuk mengetahui market orientation pada PT Gunung Hijau Masarang, maka perlu dihitung jumlah keseluruhan skor pada setiap pernyataan dimana hasil penelitian ini skor mencapai 646. Pada penelitian ini, jumlah skor ideal (skor tertinggi) yaitu 960 (tinggi) dan jumlah skor terendah yaitu 192 (rendah). Berdasarkan data yang dihimpun dari sebanyak 32 item pernyataan yang diajukan kepada 6 orang responden, maka diperolehtotal skor 646. Secara presentase, angka indeks market orientationpada PT Gunung Hijau Masarang terletak pada :

$$
\begin{aligned}
\text { Market orientation } & =\frac{\text { Jumlah Skor hasil pengumpulan data }}{\text { jumlah skor ideal (tertinggi) }} \times 100 \% \\
& =\frac{646}{960} \times 100 \% \\
& =67,29 \%
\end{aligned}
$$

Berdasarkan hasil analisis menggunakan skala likert, maka dapat diketahui bahwa angka market orientation pada PT Gunung Hijau Masarang sebesar $67,29 \%$ yang berada pada rentang angka 60\% dan angka $80 \%$ yaitu yang menunjukkan sikap setujumengenai penerapanmarket orientation berdasarkan skala MARKOR.

Hasil ini menunjukkan bahwa perusahaan berupaya memberi pelayanan konsumen sesuai dengan standar dan kualitas dengan baik.Perusahaan selalu mencari tahu tentang kekurangan dan kelemahan dalam pelayanan kepada pelanggan. Dengan cara menerima segala kritik dan saran dari pelanggan. Dengan begitu perusahaan memperbaiki dan meningkatkan pelayanan 
agar pelanggan puas. Selain itu perusahaan selalu bersikap bijaksana dalam mengatasi setiap masalah. Hal ini ditunjukkan ketika perusahaan menanggapai tentangkeinginan konsumen yang ingin menyampaikan keluhan kepada perusahaan dimana perusahaan merespon dengan baik.

PT Gunung Hijau Masarang melakukan interaksi dengan konsumen guna mencari tahu ketika terjadi perubahan kebutuhan konsumen tahu pengaruh pembelian produk menurut konsumen akan berpengaruh pada kinerja pemasaran. Perusahaan melaksanakan komunikasi formal maupun informal untuk membicarakan taktik atau strategi pesaing. Komunikasi seperti ini bertujuan untuk menjalin komunikasi antar staf, manajer atau dengan direktur mencari tahu informasi seperti diskusi kebutuhan konsumen. Perusahaan juga merespon perubahan kebutuhan konsumen seperti kepuasan pelanggan yaitu respon atau tanggapan yang diberikan para konsumen setelah terpenuhinya kebutuhan mereka akan sebuah produk, sehingga para konsumen memperoleh rasa nyaman dan senang.

\section{KESIMPULAN DAN SARAN}

\section{Kesimpulan}

Penelitian ini menunjukkan bahwa PT Gunung Hijau Masarang telah melakukan kinerja perusahaan dengan baik berdasarkan market orientation skala MARKOR. Sehingga berdasarkan hasil dan pembahasan yang dijelaskan menyimpulkan bahwa market orientataion pada PT Gunung Hijau Masarang berdasarkan skala MARKOR adalah sebagai berikut.

\section{Intelegensi Pasar}

Perusahaan melakukan kegiatan pelayanan kebutuhan konsumen untuk mengetahui respon konsumen terhadap produk. Perusahaan melakukan pertemuan secara informal dengan konsumen minimal setahun sekali untuk mengtahui apakah ada produk yang rusak atau konsumen kurang puas dengan produk. Perusahaan juga memahami dengan baik preferensi kebutuhan konsumen melalui riset pemasaran in-house secara mandiri.

\section{Penyabarluasan Integensi Pasar}

Perusahaan memahami integensi pasar seperti membicarakan secara informal tentang strategi pesaing, diskusi tentang kebutuhan secara formal maupun secara informal.Komunikasi manajer perusahaan dan bagian produksi tentang perkembanagan pasar berpengaruh terhadap produksi produk ataupun inovasi produk. Perusahaan memberikan kesempatan kepada semua staf untuk mengkomunikasin dengan menejer produksi jika ada konsumen komplain.

\section{Respon atas Integensi Pasar}

Perusahaan memahami market orientation terhadap respon atas integensi pasar. Perusahaan menerima keluhan seperti jika ada produk yang rusak, perubahan kemasan. Hal ini adalah kesempatan bagi perusahaan untuk mengkoreksi kinerja perusahaan serta sistem layanan seperti ini mempermudah mendorong perusahaan untuk lebih jeli melihan kebutuhan konsumen.

\section{Saran}

Berdasarkan perolehanhasil data, PT Gunung Hijau Masarang menyikapi market orientation dengan baik, sehinggan disarankan perusahaan mempertahankan market orientation pada intelegensi pasar, penyebarluasan intelegensi pasar, dan respon atas intelegensi pasar. Perusahaan lebih meningkatkan inovasi produk serta evaluasi pada pemasaran terutama pada pelayanan konsumen.

\section{DAFTAR PUSTAKA}

Alam, M. M., 2013, Effect of Market Orientation on Small Business Perormance in Small Town In Malaysia: An Emprical Study on Malaysian Small Firms, Journal of Strategic Marketing, Vol 1, No. 3.

Esteban A., Millan A., Molina A., Consuegra D.M., 2002, Market Orientation in

Gitosudarmo, Indriyo., 2000, Pengantar Bisnis, BPFE, Yogjakarta.

Kohli, Ajay. K and Jaworski, Bernard. J, 1990, "Market Orientation: The Construct, Research Propositions, and Managerial Implications", Journal of Marketing, Vol. 54, April.

Narver, J. and Slater, S., 1990, The effect of a market orientation on business profitability. Journal of Marketing, Vol. 54.No 10.Page: 20-35.

Rangkuti, F., 2003, Analisi SWOT Tehnik Membedah Kasus Bisnis. Gramedia Pustaka Utama, Jakarta

Riduwan., 2012, Rumus dan data dalam Analisis Statistika. Penerbit Alphabet, Bandung.

Tulenan, Steriany., 2016, Orientasi Pasar pada UD. Bintang Lima Produk Kacang Telur di Kota Tomohon, Agri-Sosioekonomi Unsrat, ISSN 1907-4298, Volume 12 (2 A) Hal: 1 - 18

Ulrich, Karl T., dan Steven D., Eppinger., 2001. Perancangan dan

Pengembangan Produk, Edisi 1,Salemba Teknika, Jakarta.

Uska, Ferry I., 2010, Business Plan. Fakultas Ekonomi UI. 